\title{
Sohm Abyssal Plain: Evaluating Proximal Sediment Provenance
}

Daniel Jean Stanley, Patrick T. Taylor, Harrison Sheng, and Robert Stuckenrath

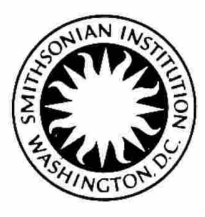

SMITHSONIAN INSTITUTION PRESS

City of Washington

1981 


\section{A B S T R ACT}

Stanley, Daniel Jean, Patrick T. Taylor, Harrison Sheng, and Robert Stuckenrath. Sohm Abyssal Plain: Evaluating Proximal Sediment Provenance. Smithsonian Contributions to the Marine Sciences, number 11, 48 pages, 23 figures, 5 tables, 1981.-The southernmost part of the Sohm Abyssal Plain in the Northwest Atlantic Basin is geographically distal with respect to the major source of Quaternary terrigenous material transported from the Canadian Maritime Provinces. An assessment of the proportion of more locally introduced sediment relative to that derived from distal sources is based largely on size and compositional analyses of Quaternary piston core samples. These data are supplemented by radiocarbon dating of selected core samples, bottom photographs, conductivity-temperature-depth profiles, and seismic records.

The premises of the study are that (a) locally derived sediment should be most abundant near high-relief bathymetric features such as seamounts and abyssal hills, and (b) such material should contain enhanced proportions of reworked volcanic debris and alteration products. Core analyses reveal that the amounts of these are directly related to proximity of volcanic oceanbottom features, and that a significant, although not total, amount of such volcanic materials recovered from cores are derived from submarine weathering of basalt. Associated with this assemblage are nannofossils, dating from the Quaternary to the Upper Cretaceous, reworked from older strata. This increased proportion of volcanic and related products and reworked faunas near seamounts and basement rises strongly implies that such topographic features continue to serve as major source terrains. Locally derived volcanic materials, however, are usually disseminated and masked on the Sohm Abyssal Plain, particularly in sectors receiving large amounts of terrigenous turbidites and biogenic suspensates, and/or undergoing reworking by bottom currents.

We propose that the volcanic fraction can serve as a useful index, or "yardstick," to interpret the role of locally derived material in abyssal plain sedimentation. A sedimentation model is developed to illustrate the premise that as access to land-derived sources diminishes, the proportion of terrigenous components is reduced while pelagic and volcanic fractions are enhanced. Thus, sediment accumulating in abyssal plains almost totally isolated from terrigenous sources would comprise significant amounts of pelagic (including wind-blown) and volcanic components. Our model illustrates that even in an abyssal plain, such as the Sohm, which has had an important and direct access to abundant distally derived terrigenous sources, particularly during the Pliocene and Quaternary, the locally supplied reworked volcanic products account for a significant fraction of the total abyssal plain sediment fill.

Official publication Date is handstamped in a limited number of initial copies and is recorded in the Institution's annual report, Smithsonian Year. Series cover Design: Seascape along the Atlantic coast of Eastern North America.

Library of Congress Cataloging in Publication Data

Sohm Abyssal Plain

(Smithsonian contributions to the marine sciences ; 11)

Bibliography: p.

1. Marine sediments-Sohm Plain (Atlantic Ocean) I. Stanley, Daniel J. II. Series: Smithsonian Institution. Smithsonian contributions to the marine sciences; no. 11.

GC383.S64 551.46'4 81-607056 AACR2 


\section{Contents}

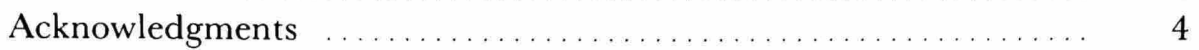

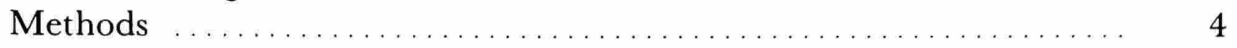

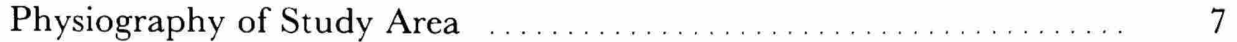

Sediment Acoustic Facies in Southern Plain ..................... 7

General Distribution ................................ 7

Perched Sediment Basin $\ldots . . \ldots \ldots \ldots \ldots \ldots \ldots \ldots \ldots . \ldots \ldots \ldots$

Other Areas near Congress and Lynch Seamounts .............. 15

Core Lithologies: General Description ........................ 16

Rates of Sediment Accumulation _.......................... 17

Textural and Compositional Characteristics ................... 20

Grain Size ...................................... 20

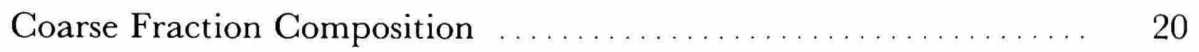

Fine Silt and Clay Fraction Composition .................. 21

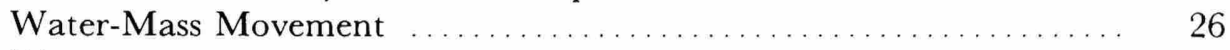

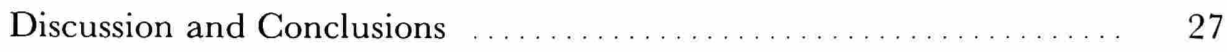

Appendix: Tables .................................. 37

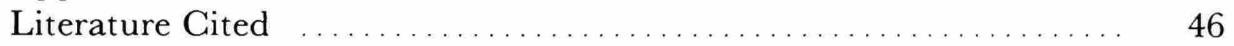




\title{
Sohm Abyssal Plain: Evaluating Proximal Sediment Provenance
}

\author{
Daniel Jean Stanley, Patrick T. Taylor, \\ Harrison Sheng, and Robert Stuckenrath
}

\section{Introduction}

Following the classic work of Heezen and Ewing (1952), studies of North Atlantic abyssal plains during the past three decades have emphasized turbidity currents as a major transporting agent in the displacement of sediment to remote regions. This process has been proposed largely as a result of piston core investigations which show that surficial Atlantic sequences commonly contain a sand fraction comprising clastic, shallow-marine or land-derived components (Ericson et al., 1961; Heezen, 1963; Horn et al., 1971). The acoustic patterns on seismic reflection profiles of the Northwest Atlantic Basin show multiple returns (termed acoustically layered) that are generally interpreted as stacked sequences of turbidites (Ewing et al., 1973). Seismic surveys in this region also indicate the presence of transparent acoustic series, primarily on topographic highs, which are believed to have a different origin (Ewing et al., 1973; Bowles, 1980). Interpretations of acoustically transparent layers are based on JOIDES deep-sea drilling results, bottom photography (Heezen and Hollister, 1971), nephelometry (Biscaye and Eittreim, 1977), and

Daniel Jean Stanley and Harrison Sheng, Division of Sedimentology, Smilhsonian Institution, Washinglon, D.C. 20560; Patrick T. Taylor, Earth Survey Applications Division, NASA Goddard Space Flight Center, Greenbelt, Md. 20771; and Robert Stuckenrath, Radiation Biology Laboratory, Smithsonian Institution, Washington, D.C. 20560. studies of water-mass motion (Laine, 1978). Various transport models, for the most part involving resuspension by bottom currents, have evolved from these investigations.

Recent reassessment of the origin of sediments in the Northwest Atlantic Basin, including the large, deep (>5000 m), T-shaped Sohm Abyssal Plain south of the Canadian Maritime Provinces (Heezen and Tharp, 1968), indicates an even more complex depositional origin (Figure 1). Biscaye and Eittreim (1977) summarize the importance of concentrated suspended material in the water masses on and above this Plain, and attribute the almost ubiquitous bottom-hugging nepheloid layer to erosion and resuspension of the seafloor by bottom-water flow. Amos and Gerard (1979), however, suggest that a nepheloid layer in the northern sector of the Sohm Plain is due to material carried southward by a transport process related to turbidity currents. The discovery of a large clockwise-circulating gyre associated with the Gulf Stream System (Worthington, 1976) has led to a modification of the classic turbidite and nepheloid layer emplacement models for this area. According to Laine and Hollister (1981), flow associated with this gyre resuspends seafloor sediment and also entrains turbidity current flows periodically introduced into the Sohm Abyssal Plain from the Canadian Maritime Margin.

All the above sedimentation schemes, and com- 


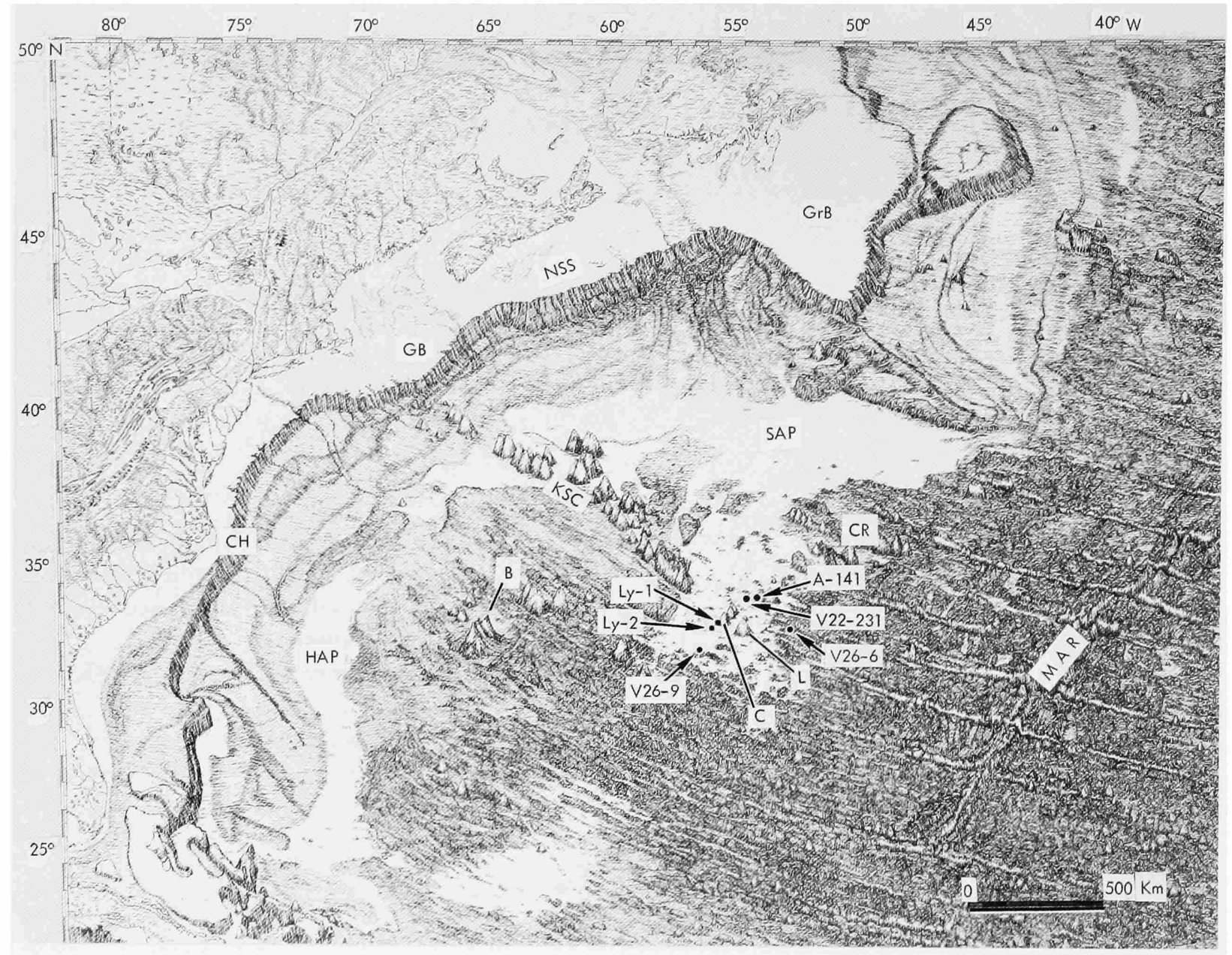

Figure 1.-Chart of Northwest Atlantic Basin (abbreviations for features cited in text: $\mathrm{GrB}=$ Grand Banks, NSS = Nova Scotian Shelf, GB = Georges Bank, $\mathrm{CH}=$ Cape Hatteras, HAP $=$ Hatteras Abyssal Plain, $\mathrm{SAP}=\mathrm{Sohm}$ Abyssal Plain, $\mathrm{KSC}=$ Kelvin Seamount Chain, MAR $=$ Mid-Atlantic Ridge, $\mathrm{CR}=$ Corner Rise, $\mathrm{B}=$ Bermuda $; \mathrm{C}=$ Congress Seamount, $\mathrm{L}=$ Lynch Seamount; core locations: $\mathrm{Ly}=$ Lynch $710-78$ cores, $\mathrm{A}=$ Allantis 153 core, $\mathrm{V}=$ Vema $2^{2}$ ) and 26 cores).

binations thereof, are generally applicable on a basin-wide scale and tend to emphasize remote provenance and long-distance dispersal of terrigenous and biogenic material by near-bottom current activity. There has been a tendency, however, to overlook the contribution of locally derived material in regional depositional interpretations. In order to focus more precisely on this potentially important aspect, we selected for study the southernmost part of the Sohm Abyssal
Plain. This area represents a geographically distal sector with respect to the major source of the Quaternary terrigenous material transported onto the plain, i.e., the Canadian Maritime Margin (Horn et al., 1971). Thus, our study will attempt to assess the proportion of more locally introduced sediment relative to that derived from distal sources. It could be assumed that the amount of locally derived sediment should be higher in cores recovered from this remote region than those collected in more proximal areas. 
The southern sector of the Sohm Abyssal Plain is bordered on three sides by abyssal hills of low to moderate relief (Heezen et al., 1959; Horn et al., 1971). Samples and seismic data were collected near the center of this region, specifically around Congress and Lynch seamounts, isolated bathymetric highs in this region (Figures 1 and 2). These data supplement more widely spaced geological and geophysical measurements previ- ously collected by others-principally from the Lamont-Doherty Geological Observatory (LDGO) - in the plain (Ewing et al., 1974:138, 229). Our working premises for this study are (a) that locally derived sediment should be most abundant near high-relief bathymetric features (e.g., seamounts, ridges, and large abyssal hills), and (b) that such material should contain enhanced proportions of volcanic debris. To test this idea,

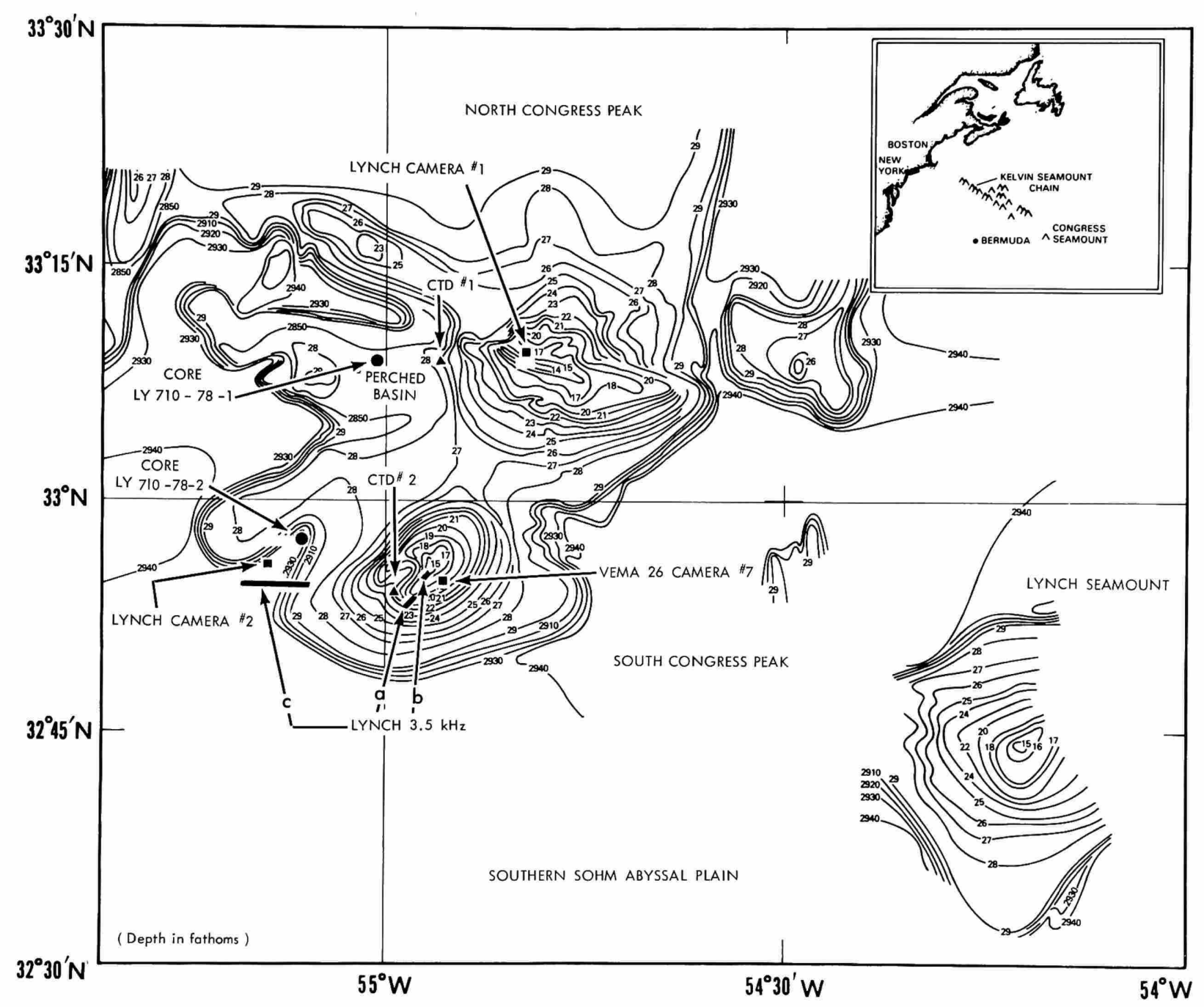

Figure 2.-Sampling stations around the Congress and Lynch seamounts in the Southern Sohm Abyssal Plain; note the perched basin on western flank of the Congress seamount (bathymetry from Lynch cruise $710-78$ in 1978; solid circles = core stations, squares = camera stations; triangles $=$ CTD stations, solid bars $(\mathrm{a}, \mathrm{b}, \mathrm{c})=3.5 \mathrm{kHz}$ profiles, shown also, in part, in Figure 10; depths shallower than 2910 fathoms given in hundreds of fathoms). 
six cores recovered on or within $220 \mathrm{~km}(120 \mathrm{~nm})$ of Congress Seamount (Figure 1) were examined: two each near the Congress, on the southern Abyssal Plain proper, and on the somewhat higher relief volcanic topography peripheral to the plain.

Acknowledgments.-We thank the U.S. Navy for supporting cruise 710-78 of the USNS Lynch and, particularly, Capt. John T. Lawrence, the officers, crew, and scientific party who ably assisted in the work at sea. Dr. David Greenewalt, Naval Research Laboratory, Washington, D.C., provided us with preliminary interpretations of the conductivity-temperature-depth data collected on this cruise.

We have benefited greatly from access to the core, bottom photograph, and seismic data libraries of the Lamont-Doherty Geological Observatory of Columbia University, Palisades, New York, and are grateful to Drs. F. W. McCoy and W. Ludwig, and to Ms. B. Batchelder and Mr. L. Sullivan for their help in providing us with data used in this study.

Appreciation is also expressed to Drs. S. Streeter, Lamont-Doherty, and C. C. Smith, U.S. Geological Survey, Washington, D.C., for identification and assistance in the interpretation of the benthic foraminifera and nannofossils, respectively.

The paper has been reviewed by L. A. Barnard, Texas A \& M University, T.-C. Huang, University of Rhode Island, and G. H. Keller, Oregon State University.

\section{Methods}

The Congress and Lynch seamounts were surveyed by the USNS Lynch (cruise 710-78) from 30 September to 6 October 1978. Bathymetric data were obtained in fathoms with the Lynch's hullmounted $12 \mathrm{kHz}$ echo-sounding system and contoured in these units; the uncorrected contours shown in Figures 2 and 3 incorporate previous hydrographic ship crossings of this feature (data obtained from the Defense Mapping Agency, Hydrographic Topographic Center Data Library,
Brookmount, Maryland). Throughout the text of this paper, depths and other units are given in metric units; in most instances, equivalent English units are presented for convenience. Seismic reflection profiler data (36 kiloJoule sparker system) collected during the Lynch cruise were supplemented by airgun ( $25 \mathrm{cu}$ in, or $0.4 \mathrm{~m}^{3}$ ) records obtained during Vema cruises 22 and 26 (8 June 1966 and 8 August 1968, Ewing et al., 1974:138, 229). The more than 1000 line-kilometers of Lynch reflection data include $554 \mathrm{~km}$ in an east-west direction and 482 in north-south and diagonal directions (Figure 3). Line spacing around the Congress ranges from 3 to $10 \mathrm{~km}$. Lynch subbottom $3.5 \mathrm{kHz}$ profiles also were obtained adjacent to and on the mount proper, in the vicinity of the two conductivity-temperature-depth (CTD) profiles shown in Figure 2. At these CTD stations a Neil Brown instrument (Brown, 1974) was used. The first station $\left(33^{\circ} 09^{\prime} \mathrm{N}, 54^{\circ} 58^{\prime} \mathrm{W}\right)$ was on the western flank of the northern Congress peak some three kilometers east of Lynch core 710-78-1; the second $\mathrm{CTD}^{\circ}\left(32^{\circ} 56^{\prime} \mathrm{N}, 54^{\circ} 57^{\prime} \mathrm{W}\right)$ was on the western flank of the southern Congress peak (Figure 2).

Seafloor photographs were taken at three stations on and near the Congress (Figure 2). Two stations were occupied during the Lynch cruise and one station on Vema cruise 26. These are situated as follows: Lynch camera station 1, $33^{\circ} 09^{\prime} \mathrm{N}, 54^{\circ} 50^{\prime} \mathrm{W}, 3110-3290 \mathrm{~m}$ (1700-1800 fm); Vema cruise 26, camera station 7 (13 August $1968)$, on the southern Congress peak, $32^{\circ} 55.2^{\prime} \mathrm{N}$, 545․ $4^{\prime} \mathrm{W}, 2850-2815 \mathrm{~m}$ (1560-1540 fm); Lynch camera station 2 on the Sohm Abyssal Plain west of the seamount, $32^{\circ} 56^{\prime} \mathrm{N}, 55^{\circ} 12.5^{\prime} \mathrm{W}$, about 5367 $\mathrm{m}(2935 \mathrm{fm})$.

Two piston cores were obtained during the Lynch cruise from the immediate vicinity of the Congress (Figure 2): core Ly 710-78-1, taken near the base of the seamount in a perched basin (or pond) near the point of thickest sediment accumulation about $20 \mathrm{~km}$ west of the northern Congress peak, is $558 \mathrm{~cm}$ long $\left(33^{\circ} 09.3^{\prime} \mathrm{N}, 55^{\circ} 00.2^{\prime} \mathrm{W}\right.$, $5207 \mathrm{~m}$, or $2847 \mathrm{fm}$, depth); core Ly 710-78-2, from the adjacent plain, returned only a few 


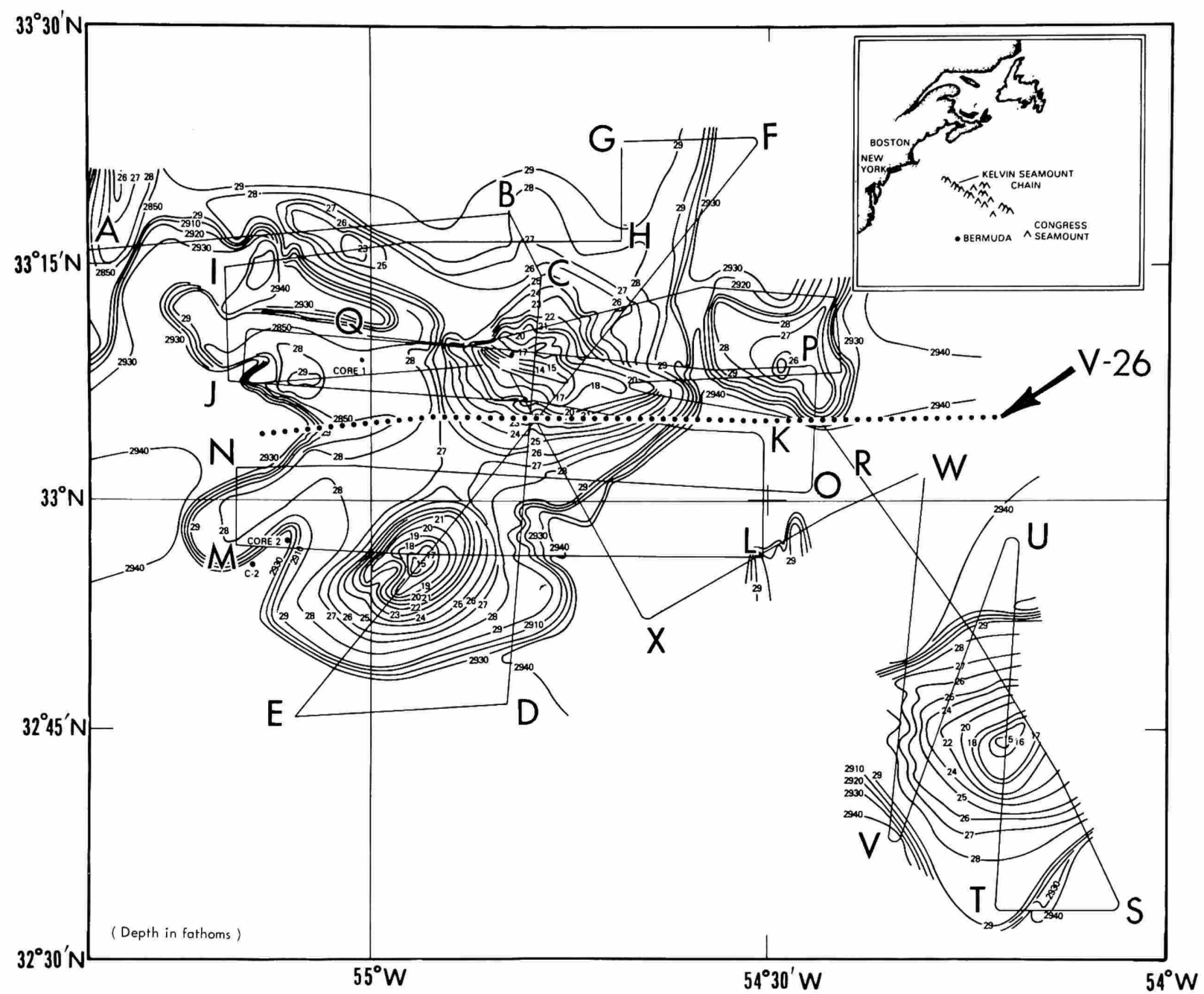

Figure 3.-Chart showing location of continuous seismic sparker profiles made on Lynch cruise 710-78 (selected records, bounded by points A through X, shown in Figures 5-9; dotted line denotes airgun profile from Vema cruise 26, shown in Figures 4A and 13; depths shallower than 2910 fathoms given in hundreds of fathoms).

centimeters of surficial sediment due to pretripping of the piston in the core barrel $\left(32^{\circ} 57.3^{\prime} \mathrm{N}\right.$, $55^{\circ} 06.6^{\prime} \mathrm{W}, 5359 \mathrm{~m}$, or $2930 \mathrm{fm}$, depth). These materials were supplemented by four L-DGO cores (for locations see Figure 1 and also Horn et al., 1971, their fig. 5). Two are located on the plain proper, northeast of the seamount: R/V Atlantis core $153-141\left(33^{\circ} 26.5^{\prime} \mathrm{N}, 53^{\circ} 48^{\prime} \mathrm{W} ; 5350\right.$ $\mathrm{m}$, or $2925 \mathrm{fm}$, depth; $1025 \mathrm{~cm}$ core length; also described by Ericson et al., 1961), and R/V Vema core $22-231\left(33^{\circ} 29^{\prime} \mathrm{N}, 54^{\circ} 10^{\prime} \mathrm{W}\right.$; $5535 \mathrm{~m}$, or 3026 fm, depth; $1507 \mathrm{~cm}$ core length). A third is located on the surrounding abyssal hills to the east of the southern plain: R/V Vema core 26-6 $\left(32^{\circ} 42^{\prime} \mathrm{N}, 52^{\circ} 36^{\prime} \mathrm{W} ; 5207 \mathrm{~m}\right.$, or $2847 \mathrm{fm}$, depth; $587 \mathrm{~cm}$ core length). The fourth was recovered on the southernmost fringe of the plain southwest of the Congress: R/V Vema core 26-9 (31 ${ }^{\circ} 43^{\prime} \mathrm{N}$, $56^{\circ} 12^{\prime} \mathrm{W}$; $5546 \mathrm{~m}, 3032 \mathrm{fm}$, depth; $609 \mathrm{~cm}$ core length).

The lithofacies of the cores are based on visual observations of split cores; only Lynch core 710- 
78-1 was x-radiographed. Core analyses also included textural measurements (percentages by weight of sand, silt, and clay fractions); these data are presented in Table 1. Compositional descriptions were made on a total of 75 samples taken from the 5 cores and presented in Tables 2 to 5 .
Mineralogical studies included the following: (1) estimated proportions of components of sand and coarse silt $(>15 \mu \mathrm{m})$ sizes (Table 1$)$ using petrographic (transmitted and reflected light) and binocular microscopes; (2) x-ray diffraction of the clay and silt fractions; (3) x-ray fluorescence

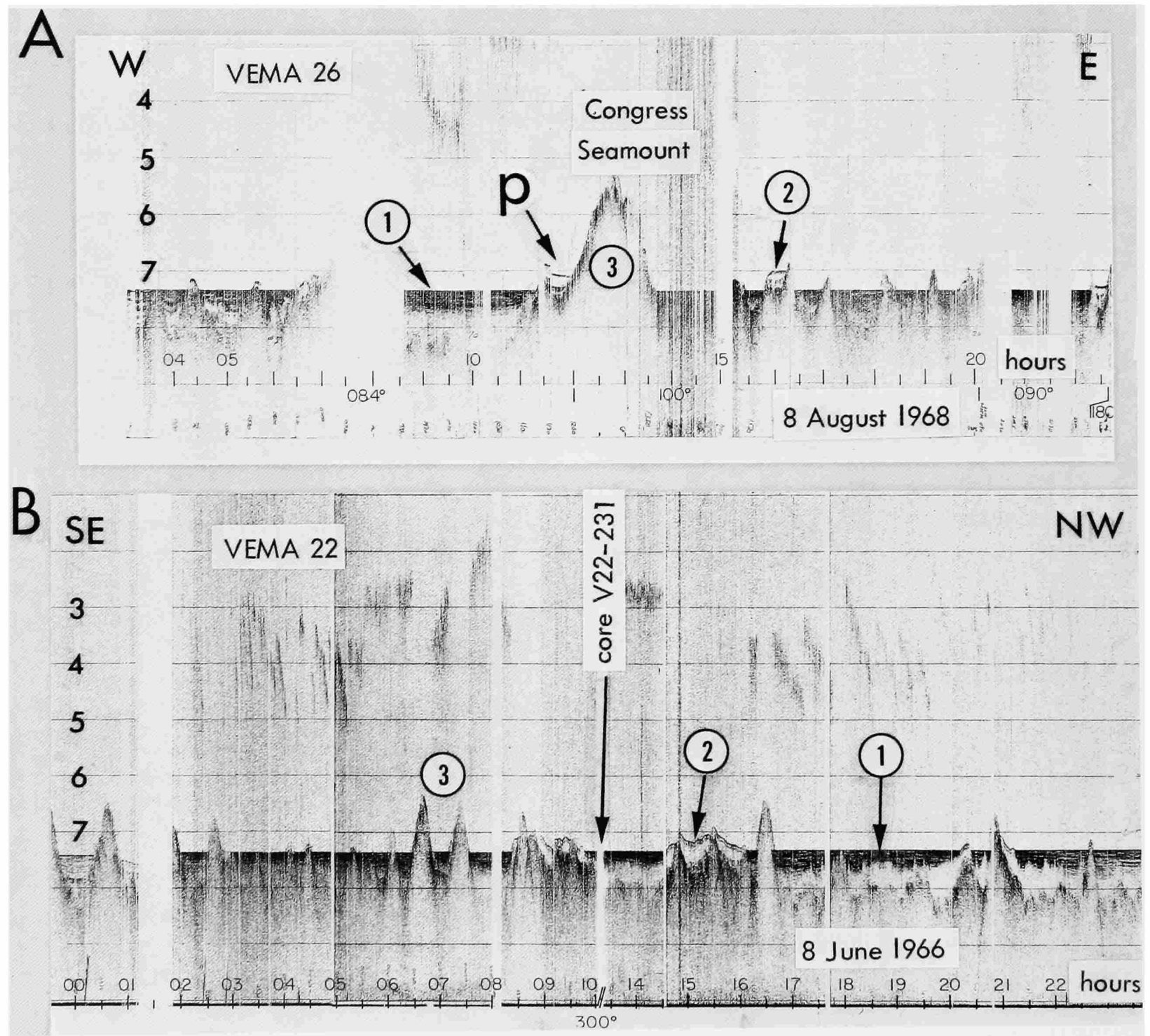

Figure 4.- Selected airgun profiles from Vema cruises 26 and 22 (profiles A and B, respectively) across the southern Sohm Abyssal Plain in, and in the vicinity of, our study area (from Ewing et al., 1974), showing examples of different acoustic seismic patterns: (1) acoustically layered, (2) acoustically transparent, (3) opaque (basement); note the perched basin (p) on the western flank of the Congress Seamount (vertical scale denotes seconds of two-way travel time; horizontal scale expressed in hours; speed estimated at 9 knots, or $17 \mathrm{~km}$ per hour). 
(counts per $0.1 \mathrm{mg}$ of sample per 200 seconds) of selected sand, silt, and clay samples; and (4) Scanning Electron Microscope (SEM, Cambridge MKIIA) and electron probe energy dispersive analysis (Tracor Northern Energy Dispersive Spectrometer) of selected silt and fine sand grains. Radiocarbon dates were determined for Lynch core 710-78-1 (5 successful dates), and from Vema core 22-231 (2 successful dates).

\section{Physiography of Study Area}

The Sohm Abyssal Plain, covering an area of about $660,000 \mathrm{~km}^{2}$, is a T-shaped province situated south of Georges Bank, Nova Scotian Shelf, and Grand Banks (Heezen et al., 1959). The southern portion of the vertical bar of the $T$ extends about $780 \mathrm{~km}(420 \mathrm{~nm})$ south of the Maritime Continental Margin and lies east of Bermuda (Figure 1). Abyssal depths range from $5120 \mathrm{~m}(2800 \mathrm{fm})$ to $5670 \mathrm{~m}(3100 \mathrm{fm})$. Bathymetric detail in the study area, between $31^{\circ}$ and $34^{\circ} \mathrm{N}$ latitude and bisected by the $55^{\circ} \mathrm{W}$ meridian, remains poorly defined. Two large seamounts, the Congress and the Lynch, are located in the approximate center of this sector of the plain (Figure 1). Results from widely spaced seismic profiles across this region are summarized by Ewing et al. (1973). The southern Sohm Plain is not a featureless region as has been generally depicted. Typical airgun profiles across the area show the near-horizontal plain broken by numerous topographic features of highly variable size and relief. Flat monotonous stretches of plain are generally less than $50 \mathrm{~km}$ wide between these highs (Figure 4).

Congress Seamount $\left(33^{\circ} 07^{\prime} \mathrm{N}, 54^{\circ} 50^{\prime} \mathrm{W}\right)$, located at the distal southeast end of the Kelvin Seamount chain, some $1114 \mathrm{~km}$ (600 nm) due east of Bermuda (Figure 2), was first charted by the United States Hydrographic Survey ship USS Congress in 1910. Its nearest large neighbors are the Wyoming and Nashville seamounts, about 150 and $210 \mathrm{~km}$ to the northwest (Tucholke and Vogt, 1979), and a previously unnamed mount, herein referred to as the Lynch Seamount, approximately $90 \mathrm{~km}$ to the southeast (Figure 2).

Congress is a twin-peaked seamount (Figures 2, 3 , and 5, profile E-F). The NE-SW trending peaks, separated by $27 \mathrm{~km}(15 \mathrm{~nm})$, lie at approximately the same depth; the northern summit is slightly shallower $(2554 \mathrm{~m}, 1397 \mathrm{fm})$ than the southern peak $(2578 \mathrm{~m}, 1410 \mathrm{fm})$. They rise 2803 $\mathrm{m}(1533 \mathrm{fm})$ and $2779 \mathrm{~m}(1520 \mathrm{fm})$, respectively, above the floor of the surrounding Sohm Abyssal Plain $(5357 \mathrm{~m}, 2930 \mathrm{fm})$. The average overall slope of the northern peak is approximately $9^{\circ}$; the slope increases toward the summit $\left(13^{\circ}\right)$, and diminishes near the base $\left(<3^{\circ}\right)$. The average slope of the southern peak is about $10^{\circ}$, the near-summit slope is $16^{\circ}$, and the basal slope $<4^{\circ}$

The depth of the Sohm Abyssal Plain around the Lynch and Congress seamounts is approximately the same. The relief of the Lynch Seamount (2642 m, $1445 \mathrm{fm}$ ), however, is somewhat less than that of the Congress inasmuch as the Lynch peak is about $179 \mathrm{~m}$ (98 fm) deeper. The basal area of the single-peaked Lynch mount is comparable in size to that of either of the Congress peaks (Figure 6).

One area of the Congress Seamount selected for detailed study is the perched basin between the western flank of the northern peak and a topographic ridge just to the west (Figure 2 and Figure 7, profile J-K). The surface of this depression lies at about $4882 \mathrm{~m}$ (2870 fm), or about 475 m (260 fm) above the Sohm Abyssal Plain. The maximum dimensions of this perched, beanshaped depression are $30 \mathrm{~km}$ in an $\mathrm{E}-\mathrm{W}$ direction and about $29 \mathrm{~km}$ in a N-S direction; its approximate surface area is $450 \mathrm{~km}^{2}$ (Figure 2).

\section{Sediment Acoustic Facies in Southern Plain}

General Distribution.-The closely spaced grid of Lynch seismic profiles near the Congress and Lynch seamounts (Figure 3) provides the means to define the distribution of two types of unconsolidated sediment in the center of the southern Sohm Plain study area. The survey reveals the configuration of (a) flat-lying, acoust- 


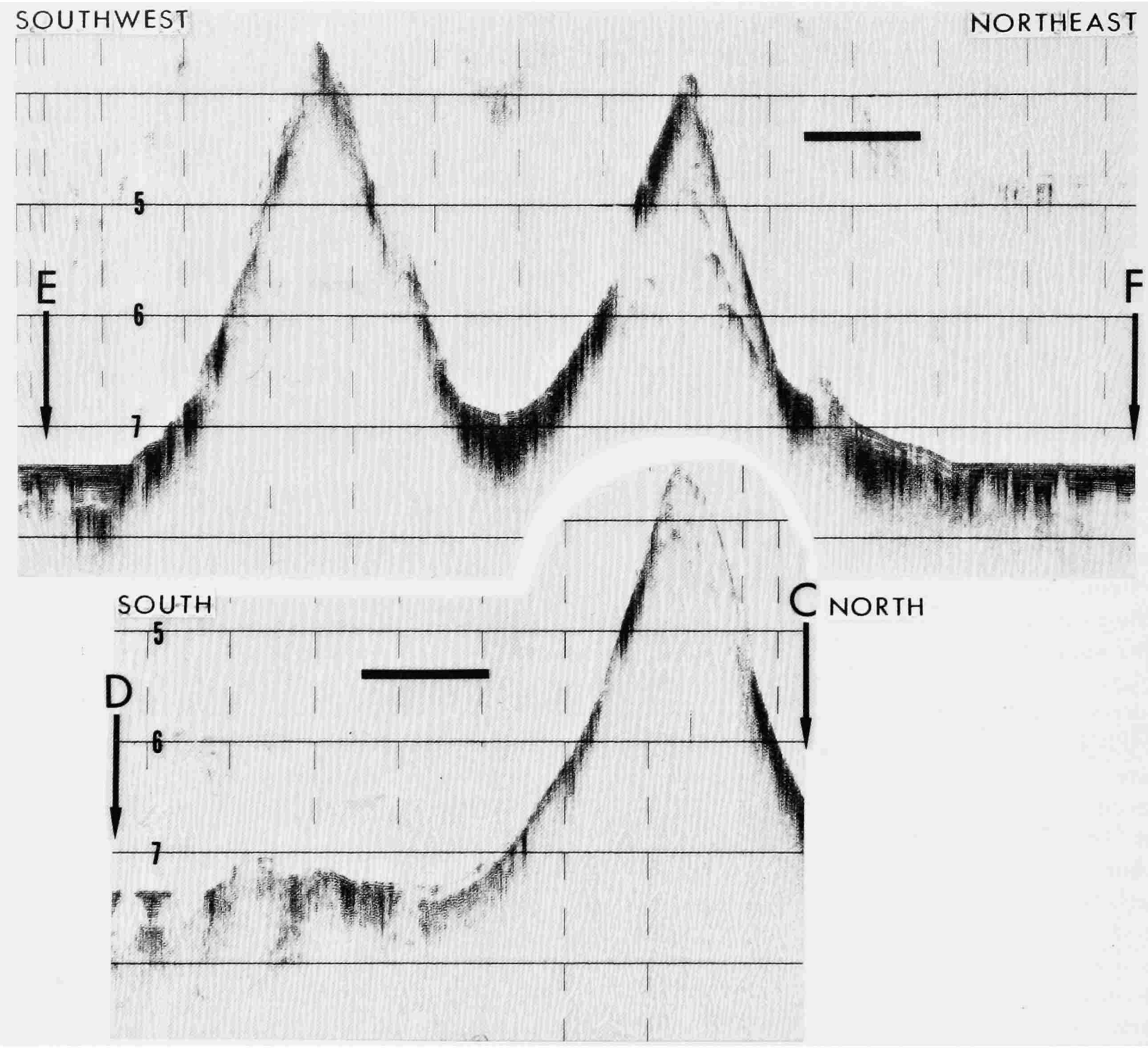

Figure 5.-Seismic profiles (30 kJ sparker) showing the twin peaks of Congress Seamount (profile E-F); note the flat-lying, acoustically layered facies forming the Sohm Abyssal Plain and acoustically transparent pattern in the saddle between two peaks (profile C-D) (letters refer to Lynch track lines in Figure 3; heavy horizontal bar represents $10 \mathrm{~km}$; vertical scale given in seconds of two-way travel time from the surface).

ically layered sediment, representing the most common reflection pattern in the plain surrounding the seamounts (Figure 4, pattern 1; Figure 7, profiles D-E and L-M; and Figure 8), and (b) the more localized, acoustically transparent pattern (Figure 4, pattern 2; Figure 7, profiles J-K, $\mathrm{P}-\mathrm{Q}$ and $\mathrm{N}-\mathrm{O}$; and Figure 9). An acoustically opaque series forms the seamount structure, and possible some volcaniclastic apron sediment (Figure 4, pattern 3; and Figures 5 and 6). This opaque pattern underlies either the acoustically layered or transparent layer, or both (Figure 7, profile N-O). The acoustically layered series occurs at depths greater than $5360 \mathrm{~m}$ (2930 fm). 


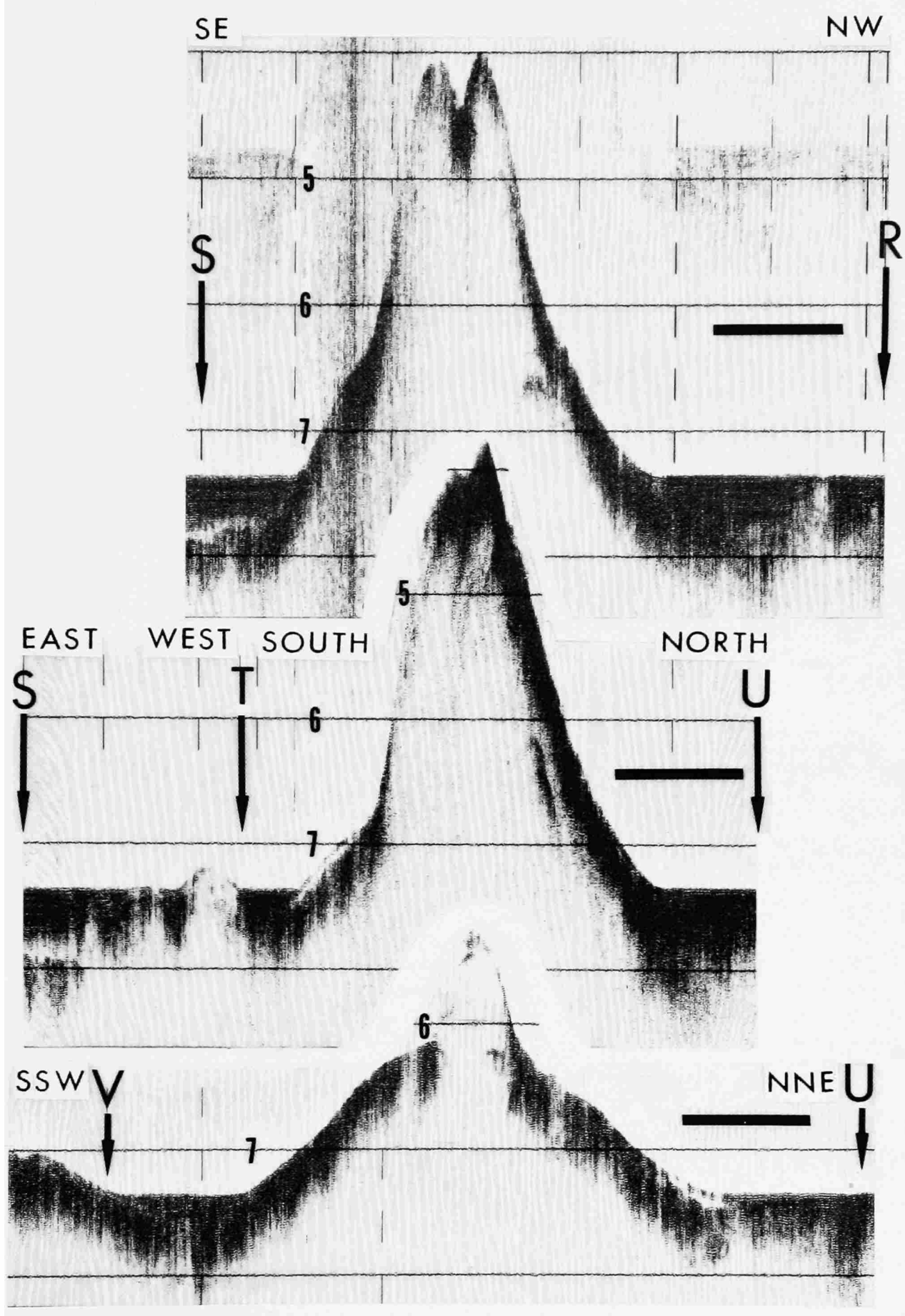

FIGURE 6.-Seismic profiles showing the single-peaked Lynch Seamount; note crater-like depression on peak (profile $\mathrm{R}-\mathrm{S}$ ), acoustically transparent pattern localized on southern flank (profile $\mathrm{T}-\mathrm{U}$ ), and acoustically layered abyssal plain facies (profile $\mathrm{U}-\mathrm{V}$ ); sharp peak on profile U-V may be a side echo (for other explanations see legend for Figure 5). 


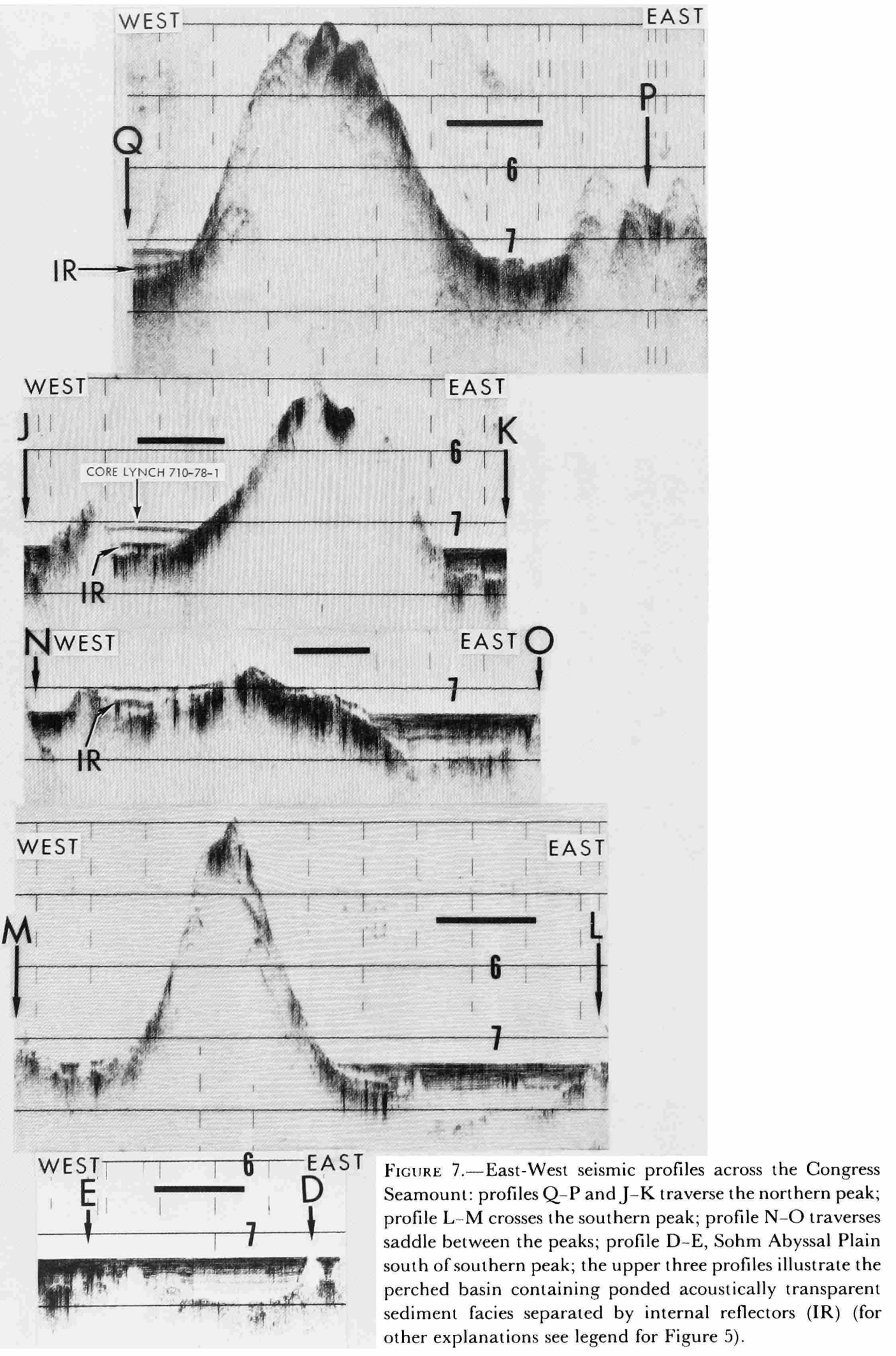




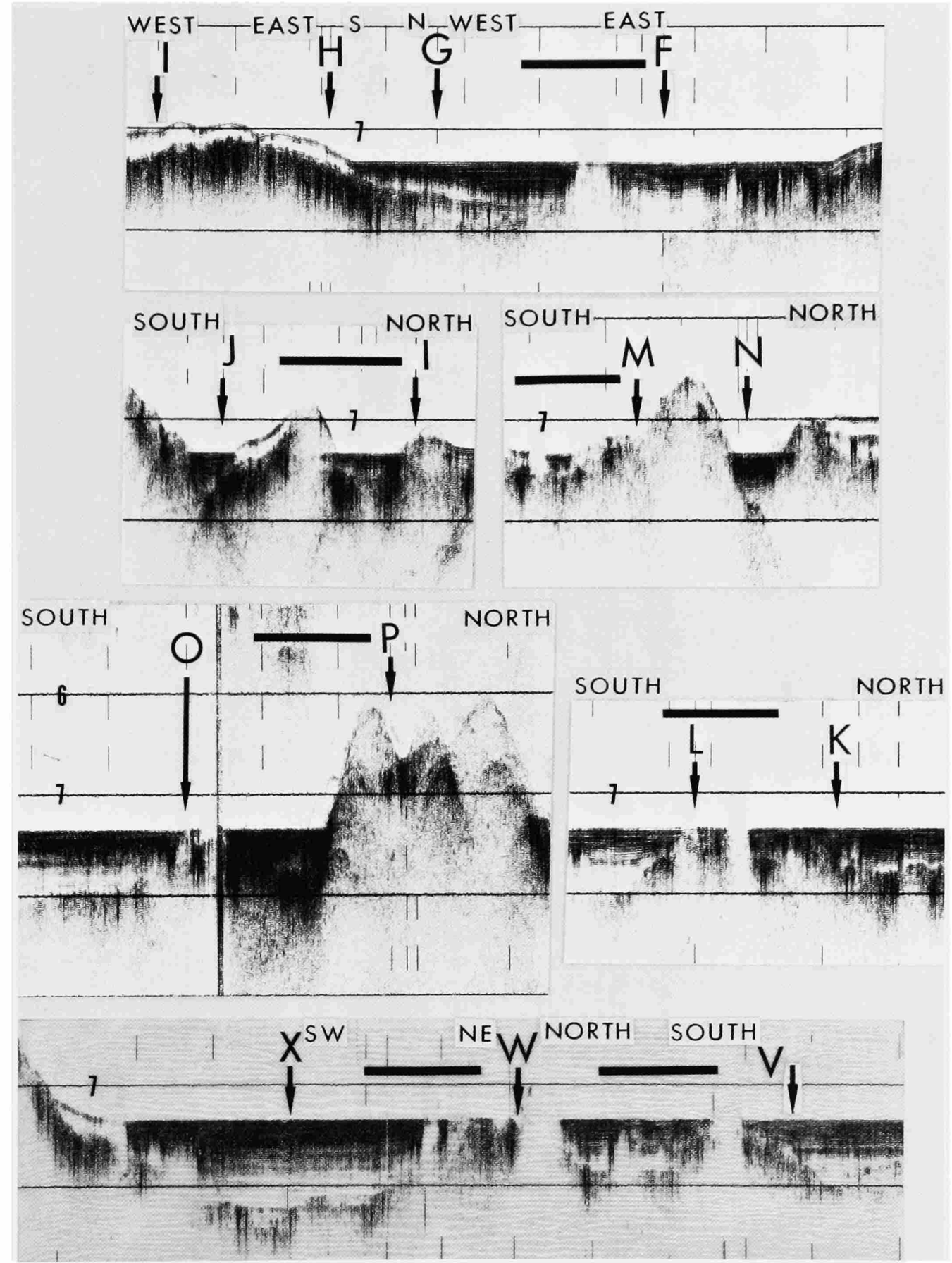

Figure 8.-Seismic profiles showing the acoustically layered reflection pattern of the Sohm Abyssal Plain sediments surrounding the Congress and Lynch seamounts; this facies abuts directly against topographically opaque hills (profiles $\mathrm{M}-\mathrm{N}, \mathrm{O}-\mathrm{P}$ ) or the acoustically transparent pattern (profiles G-H, I-J), or both; the layered facies is commonly disrupted by a reflection-free, diapir-like pattern of unknown origin (for other explanations see legend for Figure 5). 


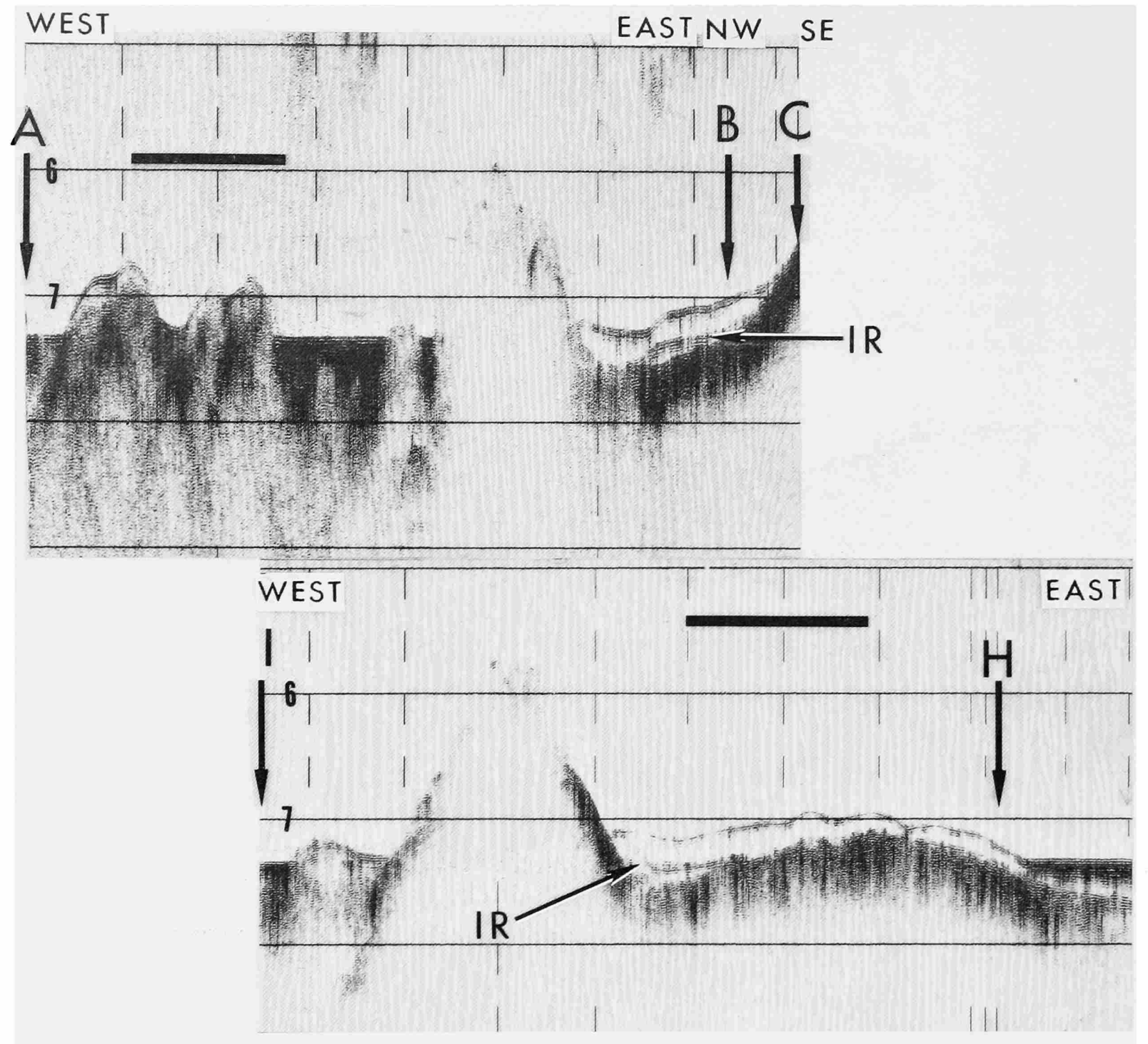

Figure 9.-Seismic profiles showing acoustically transparent sediment north of the northern Congress peak; the internal reflectors (IR) are areally more limited than in the perched basin, compare with profiles in Figure 7 (for other explanations see legend for Figure 5).

This layered series directly abuts the base of the seamounts, in sectors where the acoustically transparent layer is absent (Figure 7, profile $\mathrm{J}-\mathrm{K}$, and Figure 5, profile E-F).

The Sohm Abyssal Plain almost always displays the acoustically layered facies overlying acoustically transparent or opaque seismic reflection patterns; we presume the latter to be base- ment. Sediment thicknesses range from about 0.15 to 0.5 seconds (one-way travel time) between areas of relief on the basis of Vema (Figure 4) and Lynch profiles. The contact between the layered and the opaque basal seamount flank facies is well illustrated in the $3.5 \mathrm{kHz}$ records obtained while underway to and from CTD Station 2 on the southern Congress peak (Figure 10, profile $c$ ). 


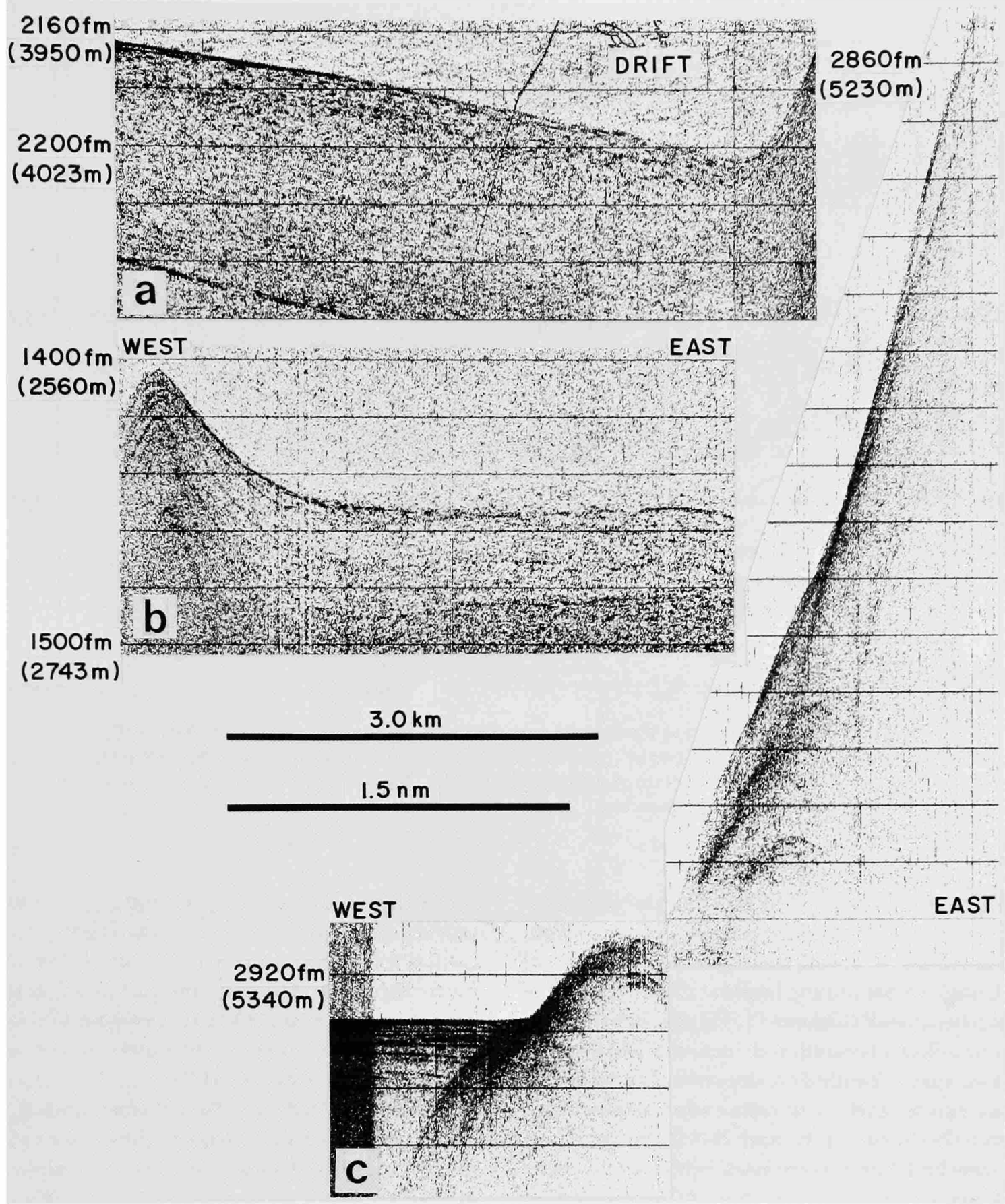

Figure 10.-Selected $3.5 \mathrm{kHz}$ subbottom profiles obtained near $(a, b)$ and west $(c)$ of the southern Congress peak (location of profiles shown in Figure 2); compare the subdued layering of sediment in profiles $a$ and $b$ with the distinctly layered Sohm Abyssal Plain sediments abutting the base of the mount $c$ (horizontal scale applies to profiles $b$ and $c$; profile $a$ made while ship was drifting). 


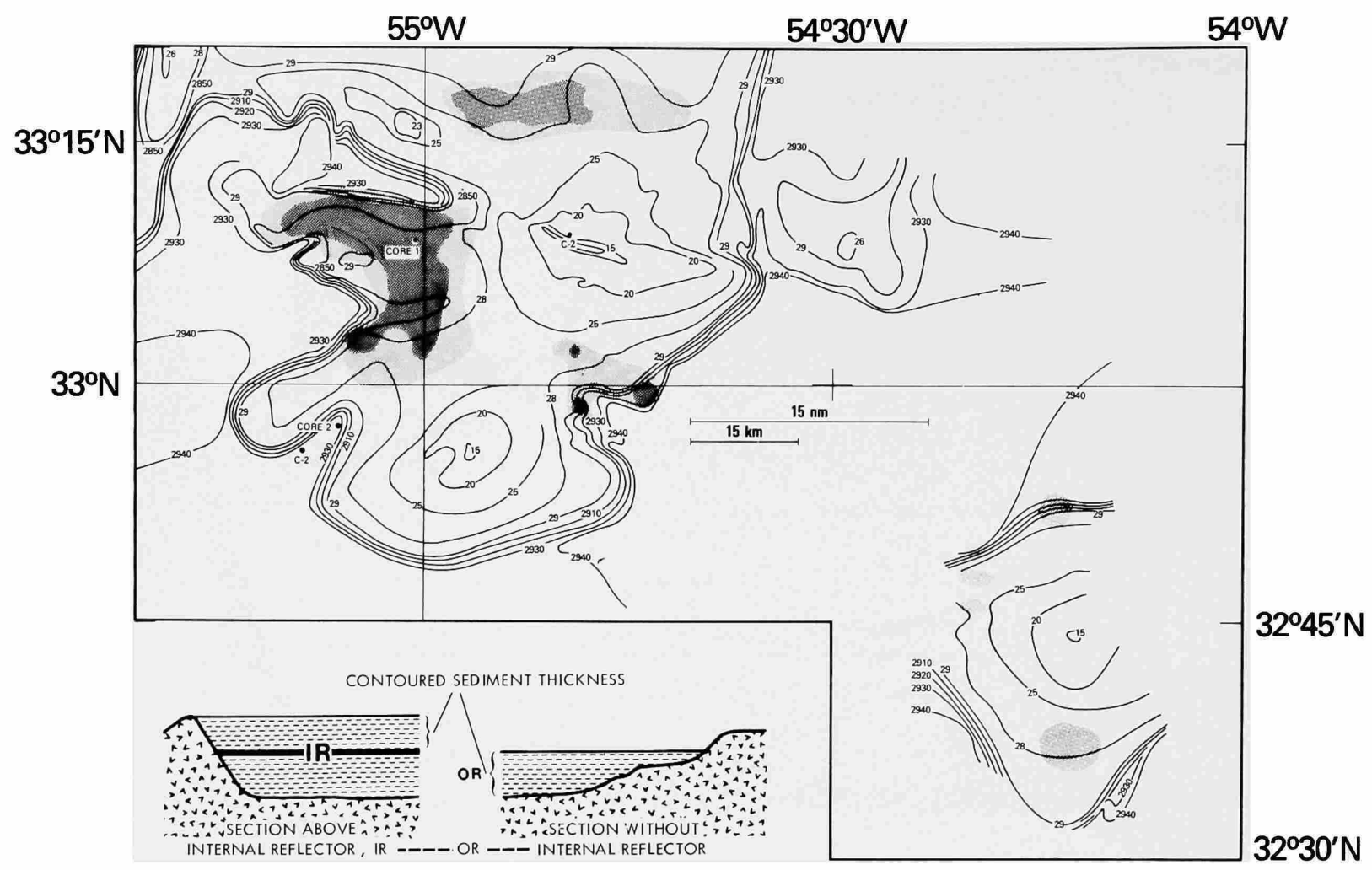

FIGURE 11.-Isopach map of acoustically transparent facies, showing two sedimentary configurations: sections above internal reflectors (IR) and sections without an internal reflecting horizon (dense stippling pattern $=$ sediment thicknesses $>0.20$ seconds of two-way travel time; lighter stippling $=0-0.20$ seconds).

Perched Sediment Basin.- The largest areal distribution and thickest section of unconsolidated sediment above the acoustic basement of the Congress Seamount is situated to the west of its northern peak (Figures 11, 12). At this location, sediment has accumulated in a saddle between the two major peaks in a depression bounded to the west by a nearly continuous topographic ridge (Figure 7, profiles $\mathrm{J}-\mathrm{K}$ and $\mathrm{N}-\mathrm{O}$ ). Sediment in this perched basin comprises both distinct and weak acoustically layered material as illustrated by Figures 7 (profile J-K) and 13. Maximum thickness of this material ranges to about $520 \mathrm{~m}$, assuming a velocity of $1.90 \mathrm{~km} / \mathrm{sec}$ (cf. Houtz, 1974). Three distinct and continuous reflectors forming the top $75 \mathrm{~m}$ thick section in Lynch profiles are an acoustic artifact, i.e., multiple reflections from the sediment-water interface caused by several bubble pulses produced by the seismic sparker. The high-resolution $3.5 \mathrm{kHz}$ records along the same traverse show marked lateral variation rather than continuity of the upper sediment layers (Figure 10).

Within this large sediment basin, another series of distinct multiple reflectors (hereafter referred to as internal reflectors, IR) occur at about 200 $\mathrm{m}$ below the sediment-water interface (Figure 7, arrow on profile J-K; Figure 13). This IR, unlike the reflecting horizon at the sediment-water interface, is probably composed of several horizons of distinct acoustic impedence, and it divides this thick sequence of weakly layered facies (Figure 


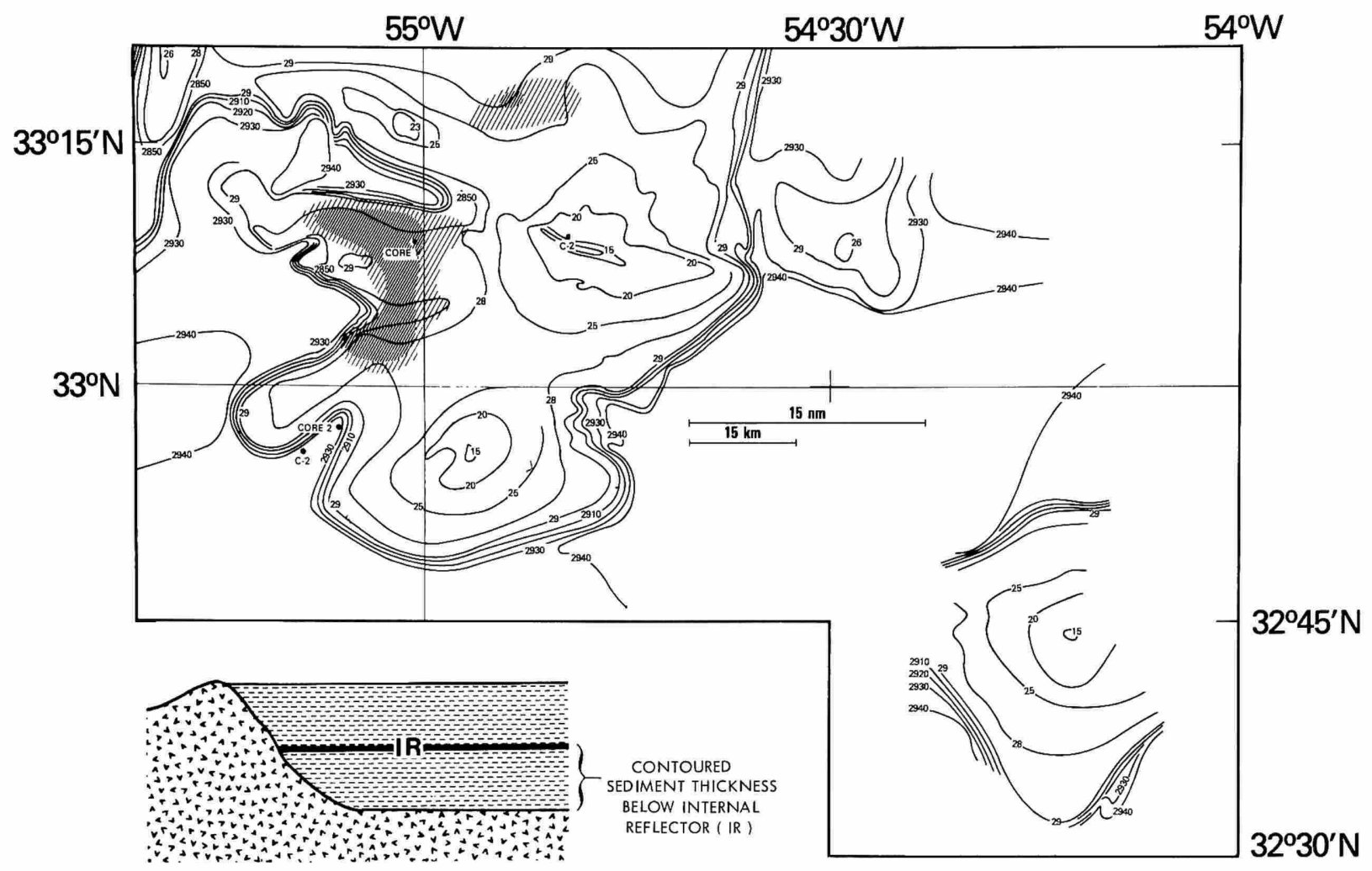

FIgURE 12.-Isopach map of acoustically transparent facies beneath internal reflectors (IR); note that IR presence is restricted to regions north and west of Congress peak (dense hatching $=$ thicknesses beneath IR $>0.20$ seconds of two-way travel time; light hatching $=0.10$ to 0.20 seconds).

13). At the thickest point $285 \mathrm{~m}$ of sediments lie above (Figure 11), and $235 \mathrm{~m}$ lie below (Figure 12), this IR.

Other Areas near Congress and Lynch SeaMOUNTS.-A depositional configuration comparable to the perched basin cited above (two layers of acoustically transparent sediment separated by strong IR) also occurs in the sector north of the northern peak of Congress (Figures 3, 9, 11, and 12). Elsewhere in the region surveyed, including the Lynch Seamount, smaller ponds of acoustically transparent sediment occur without the IR (Figures 6 and 11).

The thick (380 $\mathrm{m}$ ) accumulation of acoustically transparent material situated to the north of Congress thickens westwardly, and abuts the base of another large ridge (Figure 9, profile $\mathrm{H}-\mathrm{I}$ ). A short north-south seismic traverse west of the northern peak (Figure 8, profile I-J) shows thickening of the acoustically transparent facies in a southerly direction; the southern termination of this facies is abruptly truncated by the acoustically layered facies of the Sohm Plain. The greatest thickness of transparent series (about $140 \mathrm{~m}$ ) on the Lynch Seamount lies northwest of the peak (Figures 6, 11), while thinner accumulations are found north and south of the peak. Highresolution $3.5 \mathrm{kHz}$ profiles also show the indistinct, more poorly defined layering that characterizes the thin accumulation of acoustically transparent facies on the upper Congress flank (Figure 10, profiles $a$ and $b$ ). 


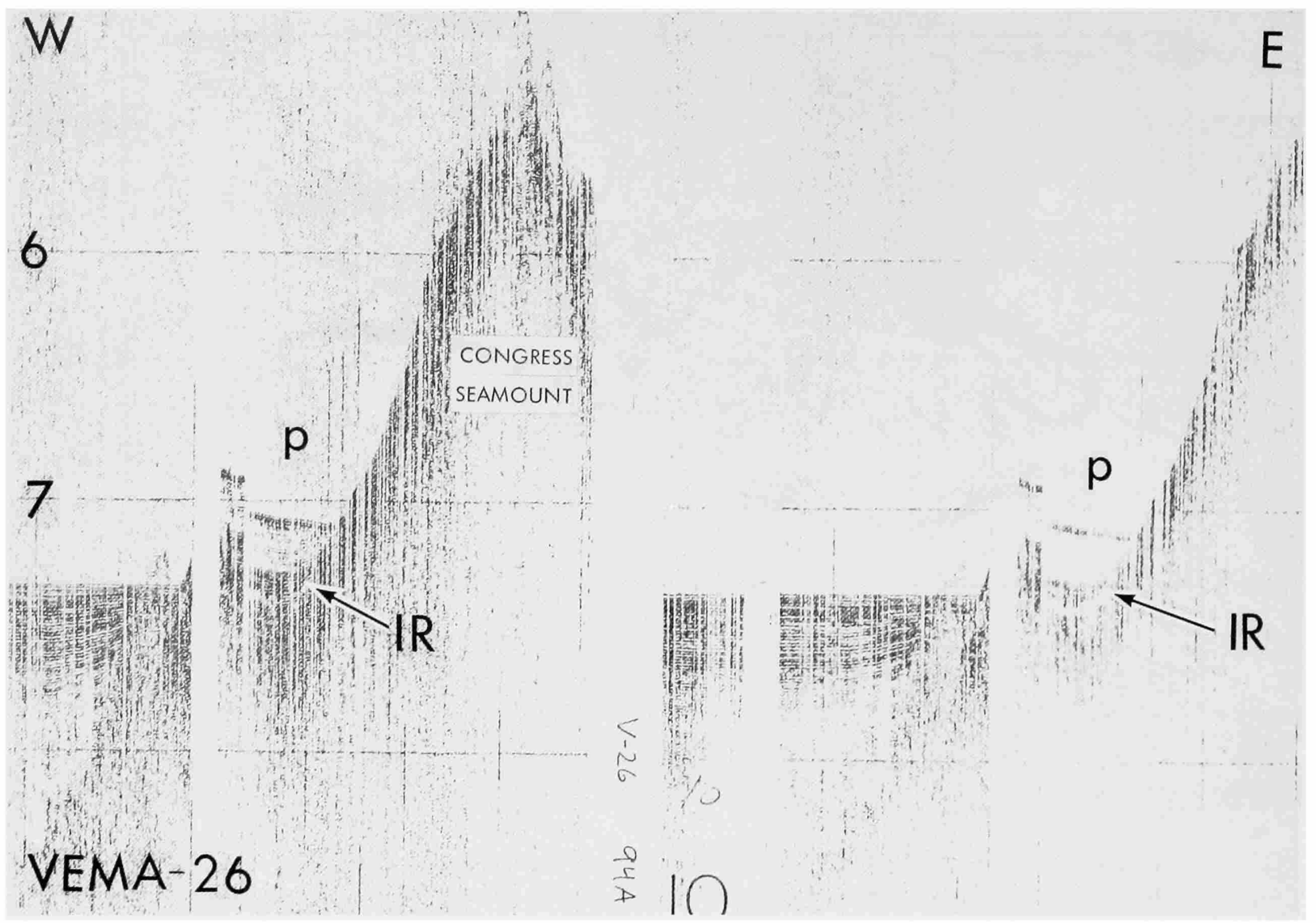

Figure 13.-Vema 26 airgun profiles of one sector of seafloor west of the Congress Seamount (for location see Figure 3, also cf. 4A), showing perched basin (p) and internal reflectors (IR); left profile is a high-pass filtered record that reveals layering in the "acoustically transparent" section above IR; right profile is a low-pass filtered record, in which layering above the internal reflectors IR, is absent; note that the reflector at the sediment-water interface at $p$ is layered in both sections suggesting that this is an acoustic artifact (both profiles were made on 8 August 1968 between 1100 and 1300 hours; reproduced from Ewing et al., 1974, with permission from the Lamont-Doherty Geological Observatory).

\section{Core Lithologies: General Description}

In this and the following sections we describe the petrologic characteristics of five cores in the following sequence (Figure 1): southern Sohm Abyssal Plain proper (Atlantis 153-141, Vema 22231, and Lynch 710-78-2); on, and adjacent to, the surrounding flanking hills (Vema 26-6 and 26-9); and perched basin on the lower flank of the Congress Seamount (Lynch 710-78-1).

The Atlantis core is by far the coarsest of the five and includes numerous, distinct, coarse sand layers, particularly in the lower two-thirds of the section (Ericson et al., 1961, fig. 11). Contacts between the layers of sand, muddy sand, and mud are generally sharp, as revealed by distinct changes in grain size and color. Sand layers, some in excess of $10 \mathrm{~cm}$, may consist of largely biogenic components (commonly foraminifera), or mixed biogenic and terrigenous fractions. In the lower part of the core, however, terrigenous material predominates. The sand layers, some graded, are 
probably turbidites. Colors, recorded only after the core had dried, are yellowish brown and olive grey.

Vema core 22-231, while only $30 \mathrm{~km}$ to the west and lying about $185 \mathrm{~m}$ deeper than the Atlantis core, displays a significantly different lithology. It is composed almost exclusively of silty clay and clayey silt, with only rare thin silt and sand layers. Coarse sand layers are generally graded and micaceous and are interpreted to be turbidites. Some finer-grained sections display bioturbation, while others comprise varve-like silt laminations that occur irregularly and could represent fine-grained turbidites. The effect of bottom-current activity, however, cannot be discounted. From the Lamont core log description, the section consists of alternating moderate- to reddish-brown (5YR4/4), pale-brown (10YR6/2), and light-olive-grey (5YR5/2) units. Some darkly streaked zones apparent in split cores consist of iron sulfide-rich layers often related to burrowing structures.

In contrast to the Vema 22 core, Vema 26-6 and 26-9 are fine textured, more homogeneous, and do not display distinct sand or silt laminae. They do, however, show localized patches of light, almost cream-colored sections 1 to $5 \mathrm{~cm}$ thick. These patches have been interpreted as weathered volcanic products, possibly palagonite (unpublished L-DGO core descriptions, 1969). Both cores recovered largely foraminiferal silty clay that includes only a minor fraction (1 percent or less) of terrigenous or nonforaminiferal biogenic components. The cores display moderate-yellowish-brown (10YR5/4), moderate-brown (5YR3/ 4) and light-brown (5YR6/4) sections. Some units show intensely burrowed structures.

Core Lynch 710-78-1, from the perched basin, most closely resembles Vema core 22-231 in terms of vertically varying grain size (clayey silt and silty clay) and a cyclic pattern of sedimentation (Figure 14). The down-core variation in the Lynch core is characterized by fine-grained ooze $(30 \%$ pelagic organisms) of different colors: pale-brown (10YR6/2) mud, alternating with yellowishbrown (10YR4/2) and moderate- to reddishbrown (5YR4/4) mud layers. Most of these layers range from about 20 to $50 \mathrm{~cm}$ thick, although two of them exceed $1 \mathrm{~m}$. Textural analyses (Table 1) show that the yellowish-brown (and in some cases grey) layers are clayey-silt ooze dominated by silt, with minor proportions of sand. The moderate- to reddish-brown ooze layers tend to be thinner and somewhat finer grained (silty clay) than the yellowish-brown muds (as shown in Figure 14). Two features of this core are a distinct angular truncation at about $435 \mathrm{~cm}$, and highly bioturbated zones with large vertical and/or horizontal (transverse) burrows located at about 210 , 330,500 and $540 \mathrm{~cm}$ (sections at 210, 330, and $500 \mathrm{~cm}$ are noted on x-radiographs, Figure 15). A distinct vertically graded sand (largely foraminifera) to mud layer in the pale-brown zone is clearly observed between 303 and $290 \mathrm{~cm}$; an xradiograph (Figure 15) shows that this unit actually fines upward to about $275 \mathrm{~cm}$. It is interpreted as a turbidite.

\section{Rates of Sediment Accumulation}

Five radiocarbon dates were obtained on samples collected from core Lynch 710-78-1 (Figure 14). Results, listed below, are in years before present, and centimeters refer to sample depth below core top: $11,070 \pm 85$ at $12-20 \mathrm{~cm}$; $11,160 \pm 500$ at $20-30 \mathrm{~cm} ; 22,390 \pm 470$ at $170-185$ $\mathrm{cm} ; 33,760 \pm 800$ at $260-274 \mathrm{~cm}$, and $>43,000$ at $310-325 \mathrm{~cm}$. Rates of accumulation in centimeters per 1000 years or $\mathrm{cm} / \mathrm{ka}$, between these dated horizons are approximately $<2,13,13.5,8$, and $<4.5$; a time integration of the overall sedimentation rate is approximately $7 \mathrm{~cm} / \mathrm{ka}$. It is noteworthy that the highest rates apply to the yellowish-brown mud immediately below the significantly more slowly accumulating Holocene core top (Figure 14). This yellowish-brown layer accumulated between 40 and $165 \mathrm{~cm}$ from approximately 20,000 to 12,000 B.P., about the time of the most recent eustatic low sea level stand, followed by a rapid sea level rise. This was a cold period during and following major glaciation at the end of the Pleistocene (Laine, 1978). We also obtained two dates from Vema 22-231, on the plain proper, nearest the Lynch core: $31,700 \pm 1400$ 

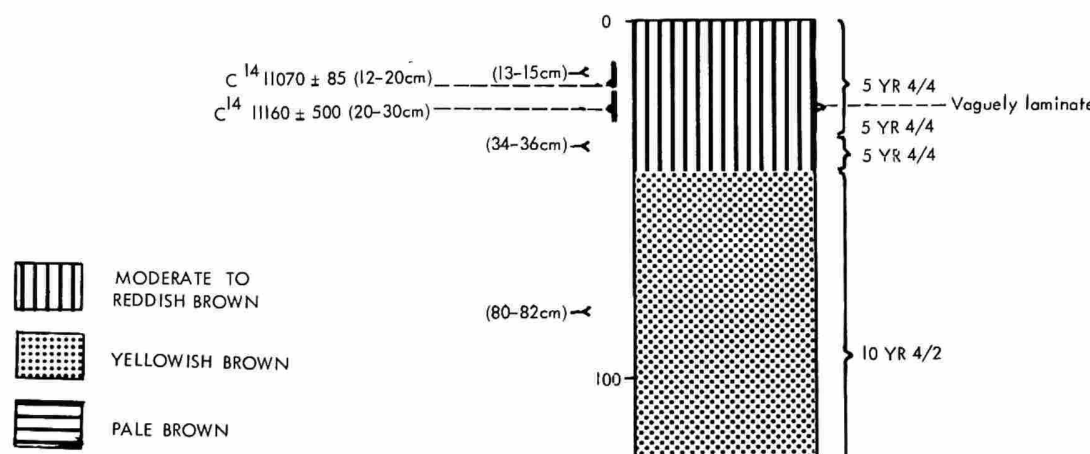

MODERATE TO REDDISH BROWN

YELLOWISH BROWN

PALE BROWN

Figure 14.-Detailed log of Lynch core 710-78-1 collected in the perched basin on west flank of the Congress Seamount (see Figure 2), showing principal sediment types, color, and physical and biogenic structures, and the position and age (in years before present) of radiocarbon-dated samples; $(5 \mathrm{YR} 4 / 4=$ moderate to reddish brown; 10YR $4 / 2=$ yellowish brown; 10YR $6 / 2$ = pale brown; dark vertical bars at right $=$ position of $\mathrm{x}$-radiographed core sections illustrated in Figure 15; see Table 1 for grain-size analyses of selected segments identified at left of $\log$ ).
100

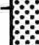

10 YR $4 / 2$

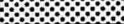
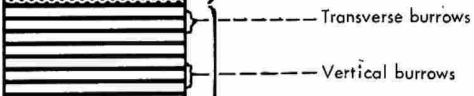

$(195-197 \mathrm{~cm}) \prec 200$

$(225-227 \mathrm{~cm}) \rightarrow$
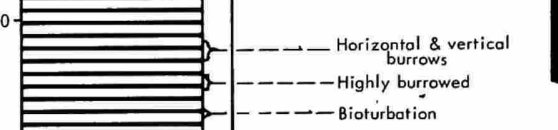

10 YR $6 / 2$

\section{更}
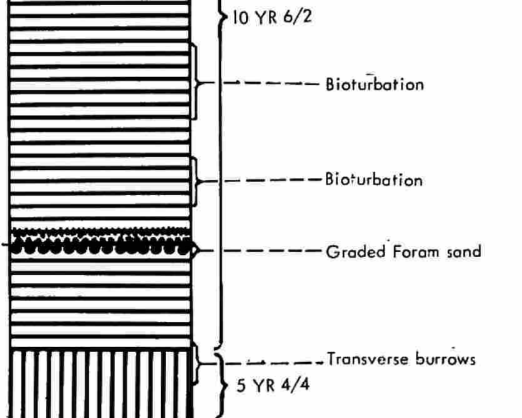

$(345-347 \mathrm{~cm})-c$

$(373-375 \mathrm{~cm})-$

$(434-435 \mathrm{~cm}) \prec$

$(443-445 \mathrm{~cm})<$

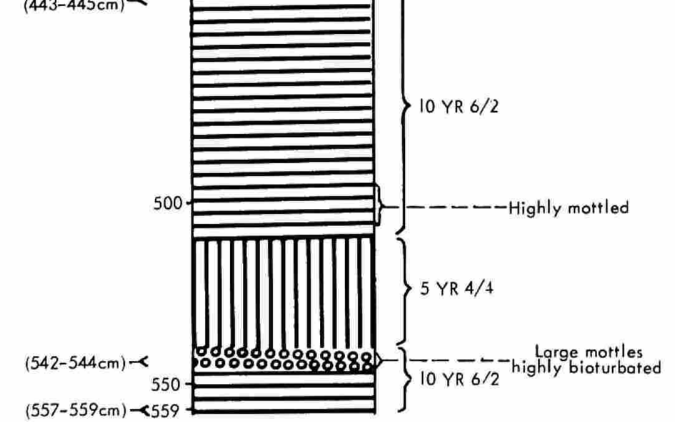



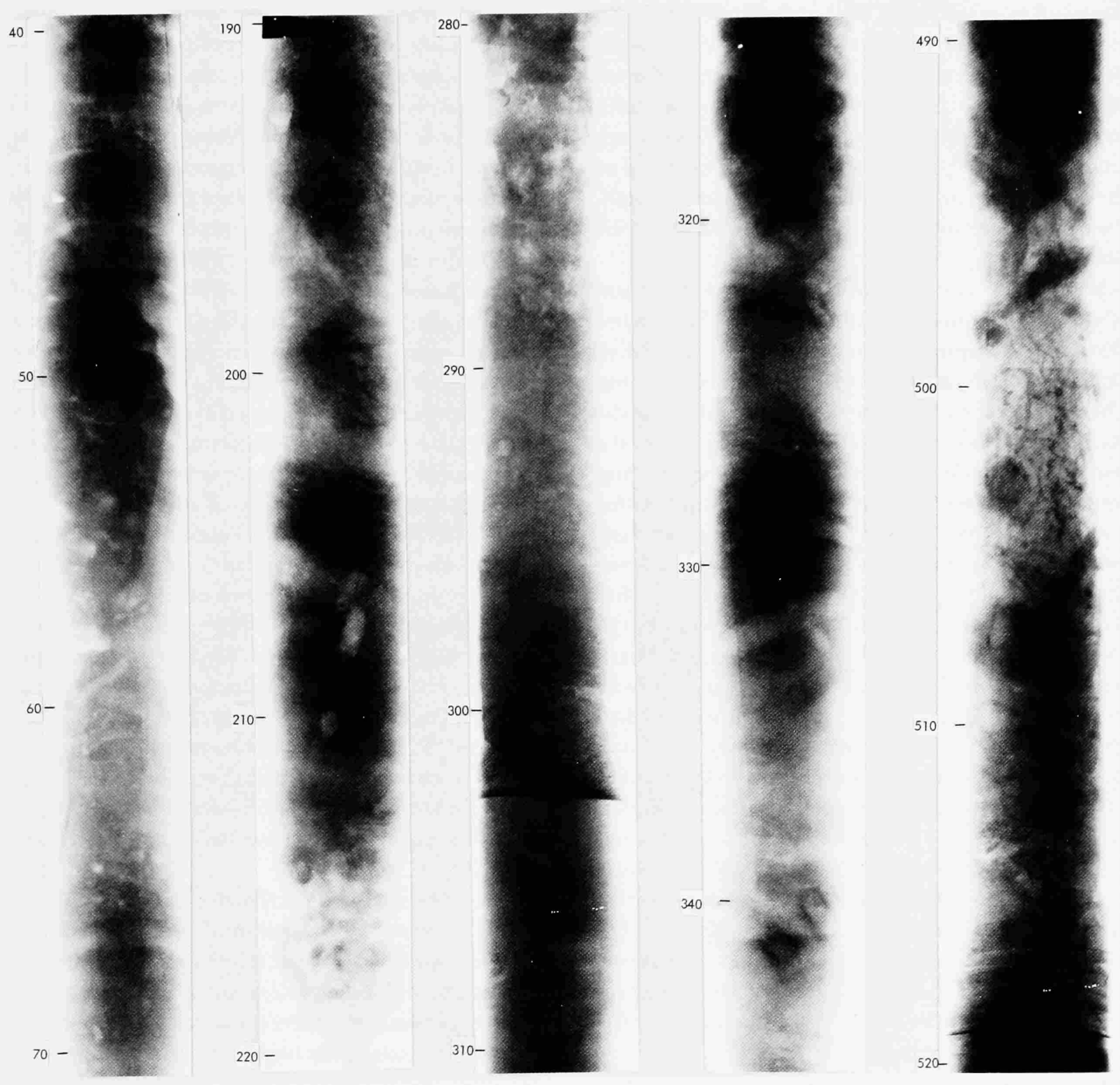

FigurE 15.-X-radiographic prints of selected sections of Lynch core 710-78-1 collected in the perched basin on the west flank of the Congress Seamount (position of sections in centimeters below core top as shown in core log in Figure 14), revealing various degrees of bioturbation including some horizontal and vertical burrows, and completely reworked mottled sections, and a graded turbidite consisting of bioclastic sand to clayey silt $(303 \mathrm{~cm}$ to $280 \mathrm{~cm})$. 
at $44-45 \mathrm{~cm}$, and $37,500 \pm 1500$ at $89-100 \mathrm{~cm}$. Rates of accumulation between these dated horizons are about 1.5 and 7.5 , and the averaged rate is about $2.5 \mathrm{~cm} / \mathrm{ka}$, lower by a factor of three than the Lynch perched basin section. In both cores, the presence of sharp contacts between layers indicate probable hiatuses. The tops of these two cores may not have been recovered and, therefore, computed rates should be used with caution.

In order to compare our values with the rates of sedimentation for areas bounding the Sohm Plain we examined data from two Deep Sea Drilling Project and one Giant Piston Core sites. These data reveal extreme areal variability in the accumulation of sediment. The rates in the southern Sohm Plain are comparable to averaged longterm accumulation values (about $12 \mathrm{~cm} / \mathrm{ka}$ ) for the Quaternary and Upper Pliocene sections forming the abyssal plain at the base of the Nashville Seamount (JOIDES drill site 382) about $150 \mathrm{~km}$ northwest of the Congress (Tucholke and Vogt, 1979). In contrast, extreme variations occur in the hills bordering the southern sector of the plain. On the lower flank of the MidAtlantic Ridge to the east, near Vema 26-6, JOIDES drill site 10 revealed a considerably reduced Quaternary section. Very low sedimentation $(<1 \mathrm{~cm} / \mathrm{ka})$ perhaps affected by sediment compaction, is recorded there (Peterson, Edgar, et al., 1970). To the west of the plain, however, radiocarbon dates from a Giant Piston Core (GPC site 5) reveal rates two orders of magnitude higher than were measured near the Congress Seamount (Silva et al., 1976). In brief, these highly variable rates can be explained in large part by regional removal and subsequent redeposition of sediment resulting from large-scale water-mass circulation (see earlier sections on sediment acoustic facies distribution and Figures 4 to 12).

\section{Textural and Compositional Characteristics}

Grain Size.-Size analysis included the sand $(>63 \mu \mathrm{m})$, silt, and clay $(<2 \mu \mathrm{m})$ fractions. These results are presented in Table 1, and graphically depicted by bars in Tables 2 to 5 .

The upper third of Atlantis core 153-141 consists of low proportions of sand; samples below 400 $\mathrm{cm}$, however, contain abundant (locally to $>65 \%$ ) sand. The silt/clay ratio in the upper third of the core is highly variable, recording alternating amounts of silty clay and clayey silt. Below 400 $\mathrm{cm}$ the core is generally characterized by greater proportions of silt than clay (Table 2).

In contrast, Vema core 22-231 is largely mud (silt and clay mixtures, Table 1) and contains a few, thin sand layers (Table 3 ). The silt/clay ratio is usually greater than 0.5 , and the core includes larger proportions of silty clay than does the Atlantis core. Vema cores 26-6 and 26-9 are even finer grained than the above, and contain only traces of sand and a range of low to very low (0.57-0.14) silt/clay ratios (Table 4). This analysis highlights the prevailing silty clay texture and generally homogeneous nature of these two abyssal hill cores.

Lynch core 710-78-1 recovered in the perched basin on the Congress Seamount flank is most similar to, but somewhat siltier than, Sohm Plain Vema core 22-231 (Table 5). One distinct turbidite (sand to clayey silt) occurs at about $300 \mathrm{~cm}$ (Figures 14, 15). Overall, this core is characterized by highly variable silt/clay ratios ranging from about 0.5 to 2.7 (Table 1 ).

Coarse Fraction Composition.-Size analyses show that, with the exception of Atlantis core 153141 , most samples contain a low proportion $(<1 \%$ or trace) of sand. A semiquantitative estimate of the proportion of the 16 most common components of the coarse fraction $(>15 \mu \mathrm{m})$-coarse silt and sand-of selected samples is depicted in Tables 2 to 5 .

The coarse fraction of the upper part of core Atlantis 153-141 is dominated by sand of biogenic origin (largely planktonic foraminifera) and carbonate fragments, with smaller amounts of other bioclastic, terrigenous, and apparently volcanic components (Table 2). In the lower two-thirds of the core, quartz, heavy minerals, and mica of sand size prevail. Volcanic products (optically 
identified palagonite, sideromelane, and chlorophaeite) are found locally, and occur as presentto-few throughout (Table 2).

The coarse-fraction composition of Vema 22231 is much more variable than for the Atlantis core: some samples are dominated by biogenic components, others by terrigenous, and some include both (Table 3). Moreover, the proportion of volcanic products is also highly variable, with the highest concentration near the core top (probably due to winnowing). The biogenic fraction is largely carbonate fragments (predominantly broken foraminifera) and coccoliths rather than unbroken foraminiferal tests. Manganese micronodules, siliceous aggregates (probable volcanic alteration products), and plant fibers are irregularly distributed in this core (Table 3).

Cores Vema 26-6 and 26-9 are distinct from the above cores primarily by their uniformly high proportion of volcanic and related products, including manganese micronodules (L. A. Barnard, pers. comm.; see also Figures 16, 17), siliceous aggregates (Figure 16), devitrified glass, palagonite, zeolites and altered feldspars (Figure 17), and pyroxenes. This assemblage argues against a dominantly diagenetic origin. Moreover, evidence for reworking is provided by the presence of quartz along with high proportions of carbonate fragments and coccoliths in the upper parts of the cores (Table 4).

Core Lynch 710-78-1 is most similar to core Vema 22-231 in that the coarse component assemblages vary vertically, and are dominated by carbonate fragments (broken foraminifera), whole foraminiferal tests, and coccoliths; siliceous aggregates and brown mica are also present, with smaller proportions of weathered glass, spicules, radiolaria, quartz, and other light and heavy minerals (Table 5). The difference between Sohm Plain core Vema 22-231 and Lynch core 710-78-1, which was obtained at more than $325 \mathrm{~m}$ above the plain on the flank of Congress, is that the latter contains substantially lower amounts of quartz, no plant matter and a somewhat higher proportion of volcanic products (Table 5), including manganese micronodules. Petrographic mi- croscope and Scanning Electron Microscope (SEM) analyses of the Lynch coarse silt fraction show variable proportions of mica, plagioclase feldspars, siliceous microfossils (Figure 18A,B), calcareous nannofossils (Figure 18C,D), foraminiferal fragments (Figure 18C,D), dolomite rhombs (Figure 18E), and angular volcanic shards (Figure 18F). Palagonite, sideromelane and/or chlorophaeite are found in every sample examined throughout the core. The abundance of these volcanic products, usually of coarse silt-size, varies considerably from sample-to-sample (Table 5).

Many of the carbonate microfossils in the Lynch core are poorly preserved (Figure 18), possibly from dissolution and recrystallization. The moderate- to reddish-brown layers contain a much higher proportion of siliceous microfossils and a lower proportion of coccoliths than the yellowishbrown layers (Figure 18A). In many samples of the latter sediment facies, as well as in the graded bed (at $300 \mathrm{~cm}$ ), mixed faunas comprising Late Quaternary (Figure 19A), Tertiary (Figure 19B,C), and Upper Cretaceous (Figure 19D) are found (C. C. Smith, pers. comm., 1980). The benthic foraminifera in the graded bed at about $300 \mathrm{~cm}$ provide evidence of downslope displacement of at least $1000 \mathrm{~m}$; their original habitat is normally about 3000 to $4000 \mathrm{~m}$ (S. Streeter, in litt., 1979). Other layers in the cores also indicate displacement of benthic foraminifera.

Further insight on modification of faunal content related to dissolution associated with depth is provided by Lynch core 710-78-2, essentially a surficial Sohm Abyssal Plain seafloor sample. This small core is a clayey silt with a trace of sand $(>63 \mu \mathrm{m})$ that consists largely of foraminifera and mica grains; it is texturally and mineralogically analogous to the upper samples of Lynch core 71078-1. The foraminifera, however, tend to be somewhat more poorly preserved than in Lynch core 1; thin tests that break easily during preparation may have been affected by deposition below the carbonate compensation depth (CCD).

Fine Silt and Clay Fraction Composition.$\mathrm{X}$-ray diffraction analyses of the less than $2 \mu \mathrm{m}$ size fraction from all cores examined confirm the 


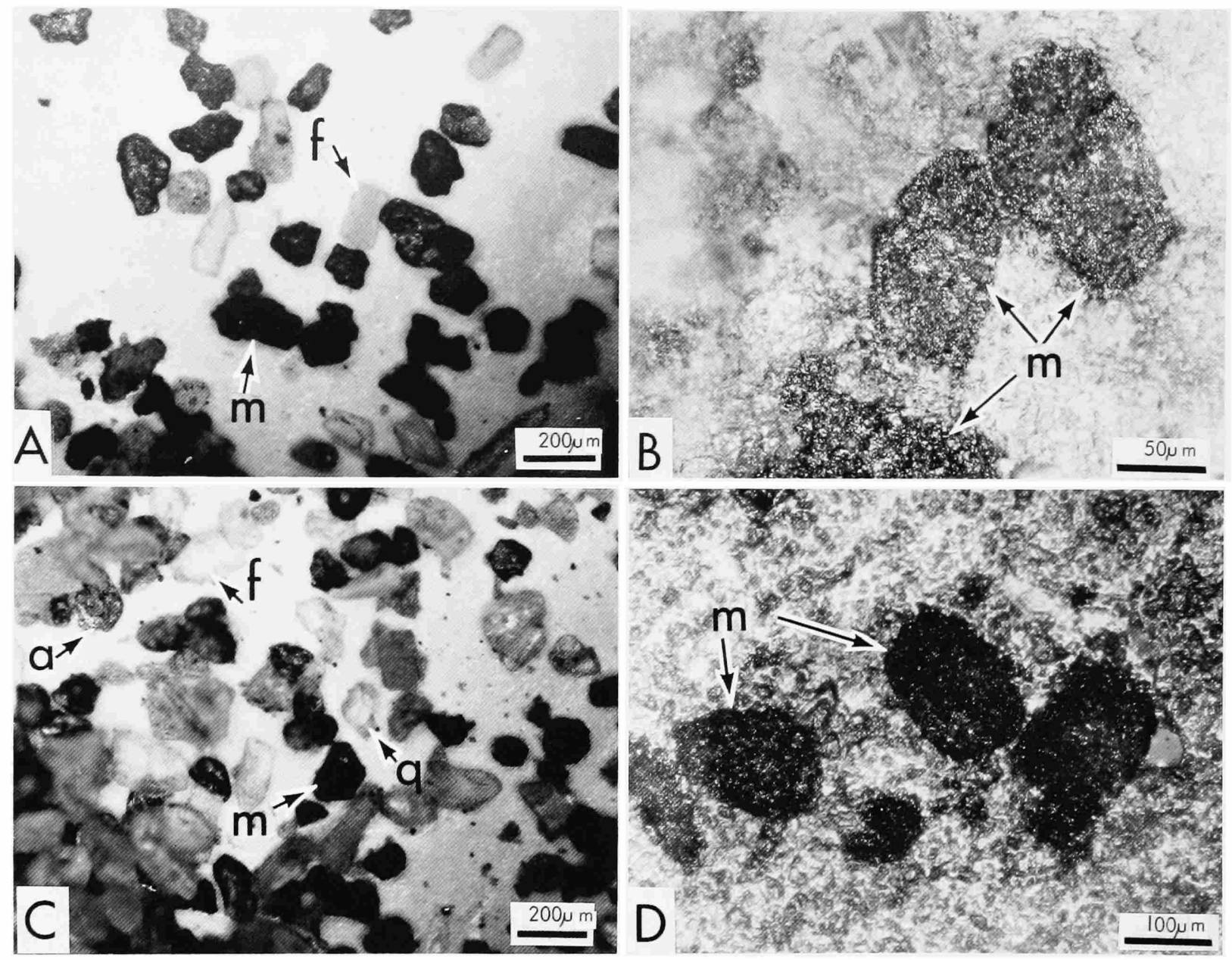

FigURE 16.-Photomicrographs of selected samples from core Vema 26-9: A and c, sand fraction from 435-437 $\mathrm{cm}$ and 503-505 $\mathrm{cm}$, respectively, showing manganese micronodules $(\mathrm{m})$, feldspars (f), quartz (q) and siliceous aggregates (a); B and D, sectioned micronodules from 453$457 \mathrm{~cm}$ and 503-505 cm, respectively, mounted in Lakeside(C) cement (matrix) and viewed in reflected light; the manganese-rich grains show no obvious internal structure (scale in $\mu \mathrm{m}$ ).

patterns of clay-mineral distribution found in this general region by Biscaye (1965).

Core Atlantis 153-141 (Table 2) illustrates that the clay-mineral suite throughout is dominated by the mica group (illite, muscovite). Kaolinite and chlorite together account for about a third of this size fraction, while feldspars and calcite account for the remainder. Montmorillonite (used in this paper synonymously with smectite) occurs only in trace amounts.

The silt-fraction suite is dominated by plagio- clase, dolomite, and calcite. In addition, mica, kaolinite and chlorite, quartz, K-feldspar, and amphibole are generally present in variable proportions.

The clay-size fraction from core Vema 22-231 (Table 3) is generally comparable to the Atlantis core. The composition of silt is also similar, but shows a slightly higher amount of dolomite.

The clay-mineral fraction of cores Vema 26-6 and 26-9 (Table 4) is markedly different from the previously discussed cores in that the proportion 

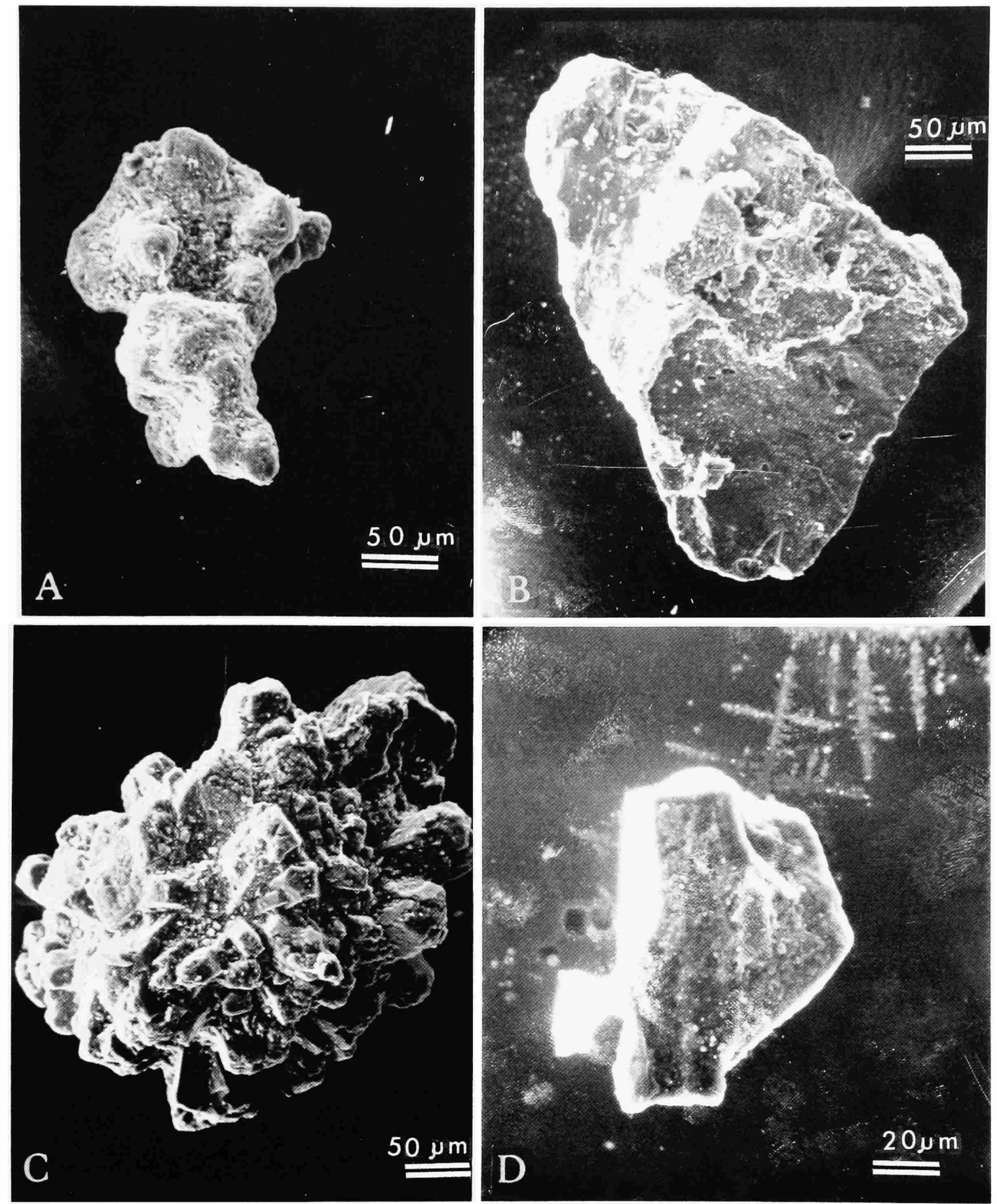

FiguRE 17.-Scanning electron micrographs of selected grains from Vema 26 cores: A, manganese micronodule (Vema 26-6, 474-476 cm); B, palagonite glass (Vema 26-9, 503-505 cm); c, zeolite (phillipsite, note twinning) in Vema 26-6, 474-476 cm; D, plagioclase feldspar, weathered and iron-coated (Vema 26-6, 45-47 cm) (scale in $\mu \mathrm{m}$ ). 


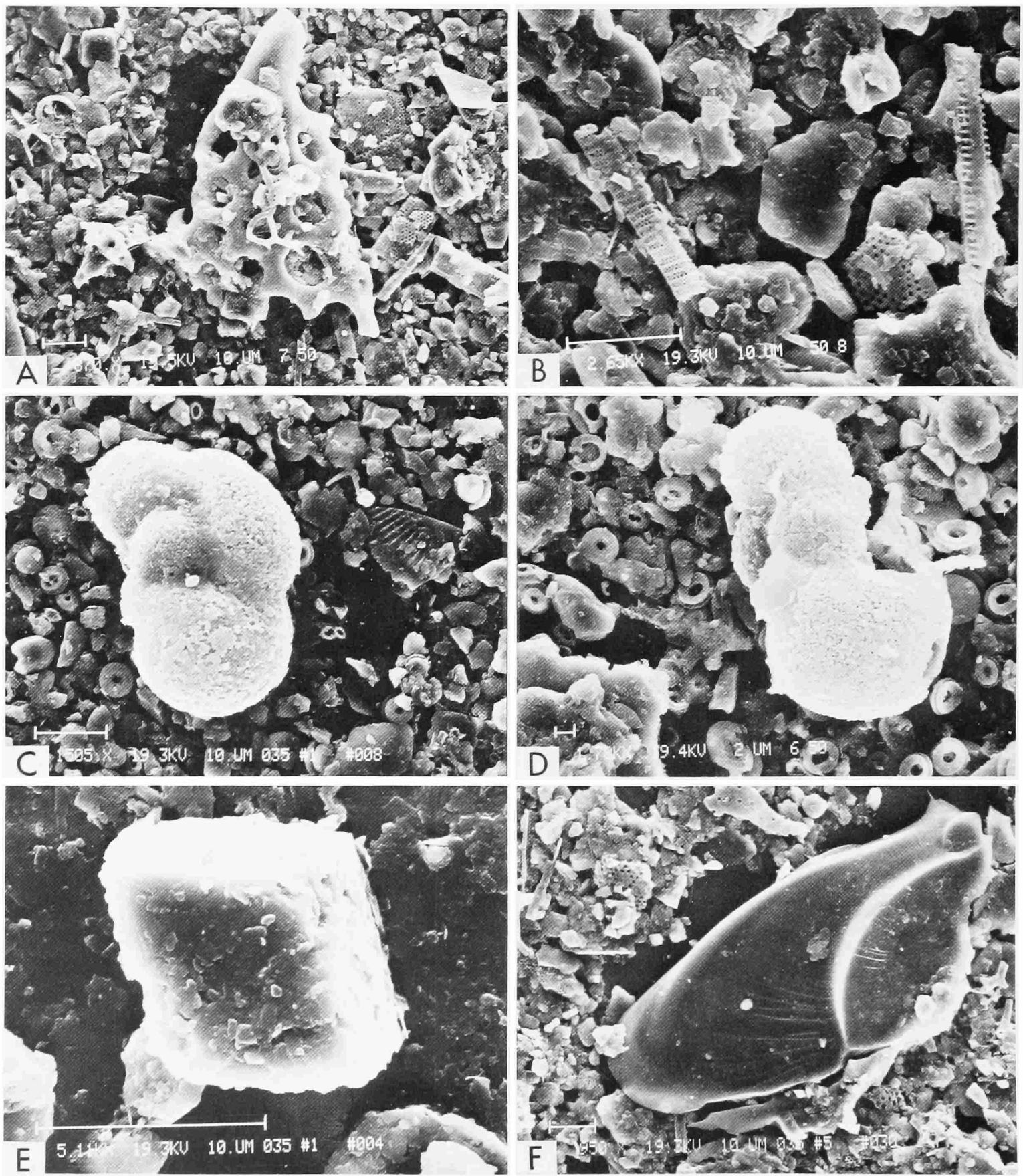

FigURE 18.-Scanning electron micrographs of selected samples from Lynch core 710-78-1: A, B, dominantly : iliceous fraction (silicoflagellates and diatom fragments) from the moderate to reddish-browr. and pale brown facies, 345 and $374 \mathrm{~cm}$, respectively, from the top of the core; C, D, carbonate fraction dominated by coccoliths and recrystallized foraminifera from the yellowish brown acies, 14 and $302 \mathrm{~cm}$, respectively; t, dolomite rhomb, $14 \mathrm{~cm}$; F, volcanic shard, $226 \mathrm{~cm}$ (scale given by thin horizontal bar in $\mu \mathrm{m}$ ). 

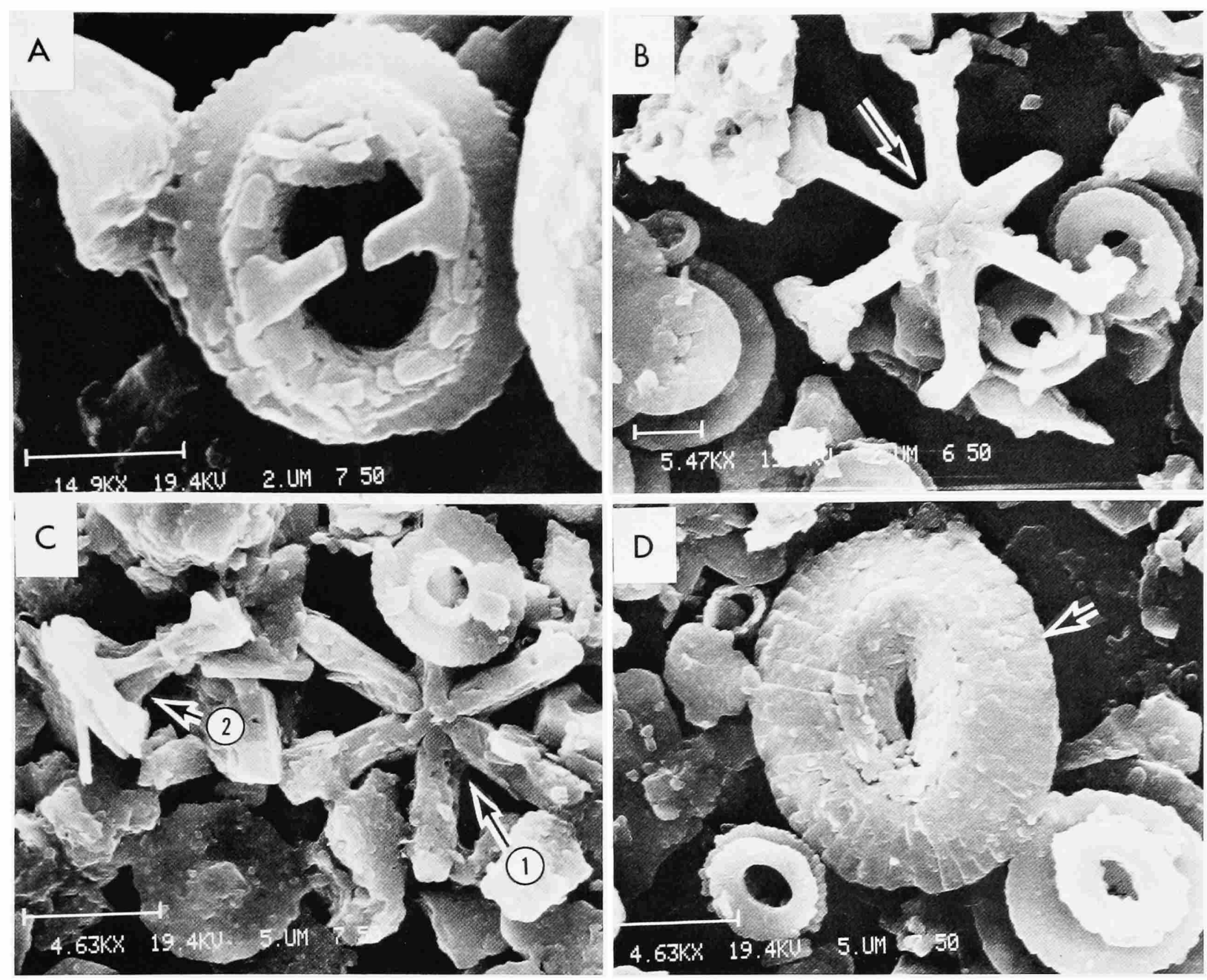

FIGURE 19.-Scanning electron micrographs of selected microfossils in Lynch core 710-78-1: A, Gephyrocapsa oceanica, a typical Quaternary coccolith species (at $543 \mathrm{~cm}$ from the top of the core) commonly found throughout this core and mixed with the reworked species illustrated in the other components of this illustration; B, Discoaster variabilis (arrow) of Middle Miocene to Pliocene age (at $301 \mathrm{~cm}$ ); c, Discoaster (arrow 1) of probable Pliocene age and Prediscosphaera cretacea of Cretaceous age (arrow 2) at $543 \mathrm{~cm}$; D, Watznaueria barnesae (arrow) of Cretaceous age at $543 \mathrm{~cm}$ (scale in $\mu \mathrm{m})$.

of montmorillonite is generally over $25 \%$, and ranges up to about $50 \%$. Moreover, the relative percentages of kaolinite plus chlorite are somewhat higher than those of the mica group. With regard to the silt fraction, these two Vema cores generally contain higher mica, kaolinite plus chlorite, and plagioclase, with notably lower calcite than the Atlantis and Vema 22 cores.
The Lynch core 710-78-1 (Table 5) clay-size samples contain montmorillonite in amounts greater than in Atlantis or Vema 22-231 cores, but lower than the two Vema 26 cores. The mica group, moreover, is more abundant than the kaolinite and chlorite components, and the proportion of quartz is about the same as in the Vema 26 cores. In the silt fraction of the Lynch core, the 
dolomite is usually present, calcite amounts are extremely variable, and the proportions of mica, kaolinite, and chlorite are more similar to the Vema 26 cores. Amphibole is not detected, but samples from the four other cores yield traces to $5 \%$. X-ray diffraction mineralogy reveals a generally lower calcite content in the silt- and claysize fractions, and X-ray fluorescence shows a substantially higher iron and, in some instances, manganese content in the moderate- to reddishbrown layers of the Lynch core.

$\mathrm{X}$-ray fluorescence analyses of manganese and iron in the clay-size fractions from the five cores reveal rather consistent concentrations of iron throughout these samples. The relative amount of manganese, however, is extremely variable (values expressed as counts per $0.1 \mathrm{mg}$ per 200 seconds; see Tables 2-5): in the Atlantis core, values range from 3.2-7.8; Vema 22, 6.2-10; Vema 26-9, 8.3-32.5; Vema 26-6, 7.1-60.9; and Lynch-1, from 1890 to 4620 . We interpret the thousandfold increase from the Atlantis to the Lynch core to be a result of the latter's proximity to the volcanic Congress Seamount. In contrast, the lowest values in the Atlantis core result from its greater distance to volcanic sources and dilution by terrigenous and biogenic components. It may be noted that energy dispersive x-ray analysis of a typical micronodule (Figure 16) of the sand-size fraction from the Lynch-1 core (Table 5) highlights the values of the two most abundant elements: manganese, 27,555, and iron, 13,365 (lesser amounts of copper, nickel, zinc, chromium, and cobalt also are measured). These results are comparable to electron microprobe analyses from Vema 26 cores that indicate some micronodules of coarse silt and fine sand size (Figure 17A) are comprised largely of manganese, iron, and nickel. We note that these manganese micronodules are associated with palagonitized glass (Figure 17B), zeolites (probably phillipsite, Figure 17C), smectites (montmorillonite, Table 4), and plagioclase feldspar (Figure 17D). This assemblage occurring in Vema 26 cores 6 and 9 is generally diagnostic of altered volcanic materials (cf. Peacock and Fuller, 1928; Arrhenius, 1963; Honnorez, 1978; Stone- cipher, 1978; Scott et al., 1979). Some of these products, such as smectite, may also have been derived from land sources.

\section{Water-Mass Movement}

The general circulation in the Atlantic, summarized by Wüst (1949; and Heezen and Hollister, 1971), shows the dominance of the Arctic and Antarctic water masses on abyssal circulation. A recent hypothesis concerning the circulation in the Northwest Atlantic proposed by Worthington (1976, fig. 11) shows a major NNE-SSW elongated gyre related to the Gulf Stream system. This large clockwise-rotating gyre is located east of Cape Hatteras, extends to about $40^{\circ} \mathrm{W}$ longitude, and is positioned over the Bermuda Rise and most of the Sohm Abyssal Plain. It is believed to influence the circulation pattern of the deeper waters, including those above the southern Sohm Abyssal Plain (Schmitz, 1977; Laine, 1978).

Two CTD vertical profiles through the water column were made on the western flanks of the Congress Seamount to ascertain the nature of the intermediate and deep waters in the study area. CTD Station 1 was situated on the perched basin about $3 \mathrm{~km}$ east of core Lynch 710-78-1, and CTD Station 2 was obtained on the southern peak (Figure 2). Three distinct water masses are recognized: North Atlantic Central Water, extending from the surface to a depth of about $930 \mathrm{~m}$ $(510 \mathrm{fm})$; a second layer, about $170 \mathrm{~m}$ thick, composed in part of Mediterranean Water, ranging from $930 \mathrm{~m}(510 \mathrm{fm})$ to about $1100 \mathrm{~m}(600$ fm); and below this, North Atlantic Deep Water, extending almost to the bottom of the profiles on the flanks of the seamount. The presence of Antarctic Bottom Water $\left(-0.5^{\circ} \mathrm{C}, 34.65 \%\right.$ ) is suggested by the lowermost readings of the temperature-salinity curve. The profiles indicate the possibility of slight mixing of Antarctic Bottom Water with North Atlantic Deep Water at, and just above, the sediment-water interface on the lower flanks of the seamount and on the abyssal plain (D. Greenewalt, in litt., 1979). While these data are admittedly limited, they tend to support the 
oceanographic model of Wüst (1949), Heezen and Hollister (1971, fig. 9.45), and others that show the northward extension of the Antarctic Bottom Water to the region encompassing the southermost part of the Sohm Abyssal Plain.

Since current-meter data are lacking, an indication of water flow and direction is obtained by noting the nature of bedforms recorded by compass-oriented bottom photographs. Three camera stations located around the Congress Seamount (Figure 2), reveal predominant transport from SSE to NNW. This flow direction at the three localities was determined from ripple marks (Figures 20, 21), craig-and-tail features (Figure 22), coarse lag accumulated against obstacles on the bottom (Figure 20A), and asymmetrically deformed mud structures (Figure 22). Although this bottom transport pattern may probably represent only recent and short-term dispersal, it is noteworthy that (a) the isopach map indicates localized thickening of sediment south, north, and west of both Lynch and the northern peak of Congress (Figure 11), and (b) selected seismic profiles show accumulation of transparent acoustic series east of obstacles (Figure 9, profile $\mathrm{H}-\mathrm{I}$ ). These latter observations could be interpreted as the result of long-term sediment dispersal trends toward the north and west quadrants. These patterns tend to support the oceanographic model of a westerly-directed return flow of the southern leg of the Gulf Stream Gyre above the Sohm Plain study area (Worthington, 1976; Laine, 1978).

\section{Discussion and Conclusions}

A review of sedimentation models in the abyssal plains of the Atlantic and other world oceans reveals an emphasis on gravitative processes, largely turbiditic, and long distance dispersal of terrigenous material, primarily sands (e.g., Heezen and Laughton, 1963). There is, in fact, ample documentation for the Northwest Atlantic Basin that the processes of turbidity currents and related gravity flows of sediment account for a significant proportion of abyssal plain deposits, especially the sands (Horn et al., 1971; Pilkey et al., 1980). In addition to this particular landderived component, most workers also call attention to the contribution from clastic particulate matter, of both terrigenous (fine silt and clay) and biogenic (largely planktonic tests) origin, which settle from suspension. The deposits from these two differing modes of sedimentation have been interpreted from seismic profiler data and core analyses. Sediments lacking internal acoustic reflectors ("acoustically transparent" layers) are generally inferred to be pelagic or resuspended deposits which may be composed of well-bedded clays (Fox et al., 1967), foraminiferal ooze with clays (Taylor and Hekinian, 1971), or a complex mixture of clay, sand, and carbonate-rich layers (Silva et al., 1976). The relative proportion of carbonate tests within these pelagic sediments, largely foraminifera and coccoliths, tends to be highest in areas shallower than the carbonate compensation depth (CCD). In contrast, distinct acoustic reflectors revealed by seismic profiler data and coarse silt- to sand-sized sediment recovered in cores are generally thought to have formed as turbidites.

Recent studies show that clay- to sand-size sediments emplaced by either turbidity currents or pelagic suspensate deposition can be, and probably in most instances are, modified by the action of bottom currents (Heezen and Hollister, 1971; Laine, 1978). Evidence for this bottom-current erosion in the southern Sohm Abyssal Plain study area includes lineated bedform features revealed by photographs (Figure 22), textural properties of the coarser-grained fractions (Hubert, 1964), and the age measurement (in excess of 30,000 yrs B.P.) near the top of core Vema 22-231, which reveals a truncated upper sediment layer.

All of the above depositional mechanisms emphasize distal transport. We note in abyssal plain studies, however, that the role of proximal or more local-intrabasinal sediment source and dispersal (in particular, the displacement of volcanically derived sediments, cf. Heath and Dymond, 1977 ) is for the most part neglected. This is indeed surprising if one views a physiographic chart of 

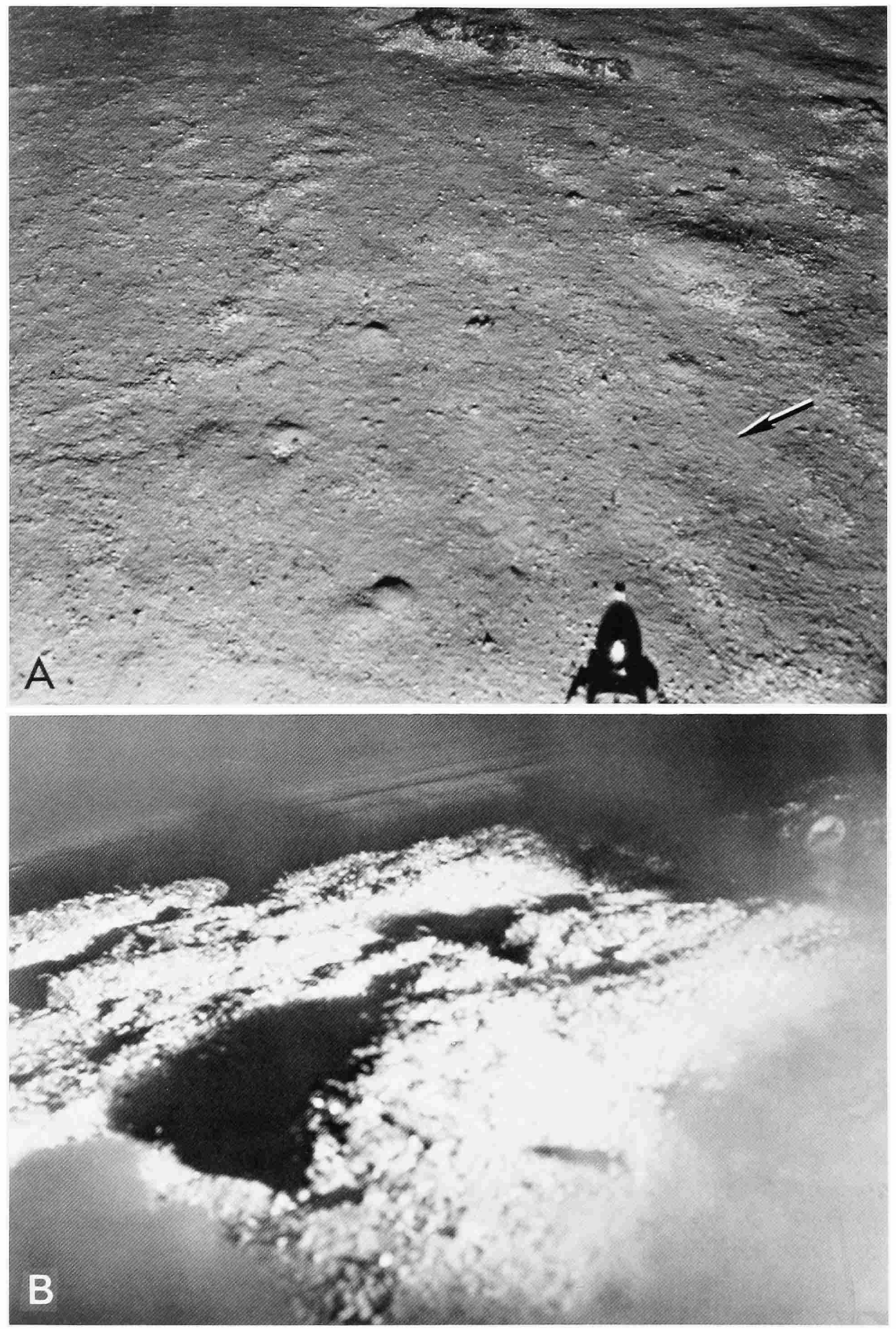

Figure 20.-Lynch 710-78 camera station 1, oblique view bottom photographs on the northern Congress peak (between 3110-3290 m, location shown in Figure 2): A, subdued asymmetric ripples of sand and mud transported toward NNW (arrow), note coarse lag against small outcrop in background; B, mixed biogenetic-volcanigenic sediment veneer of bedrock, presumably volcanic, note distinctly rippled sediment in background (compass diameter $=6.3 \mathrm{~cm}$ ). 

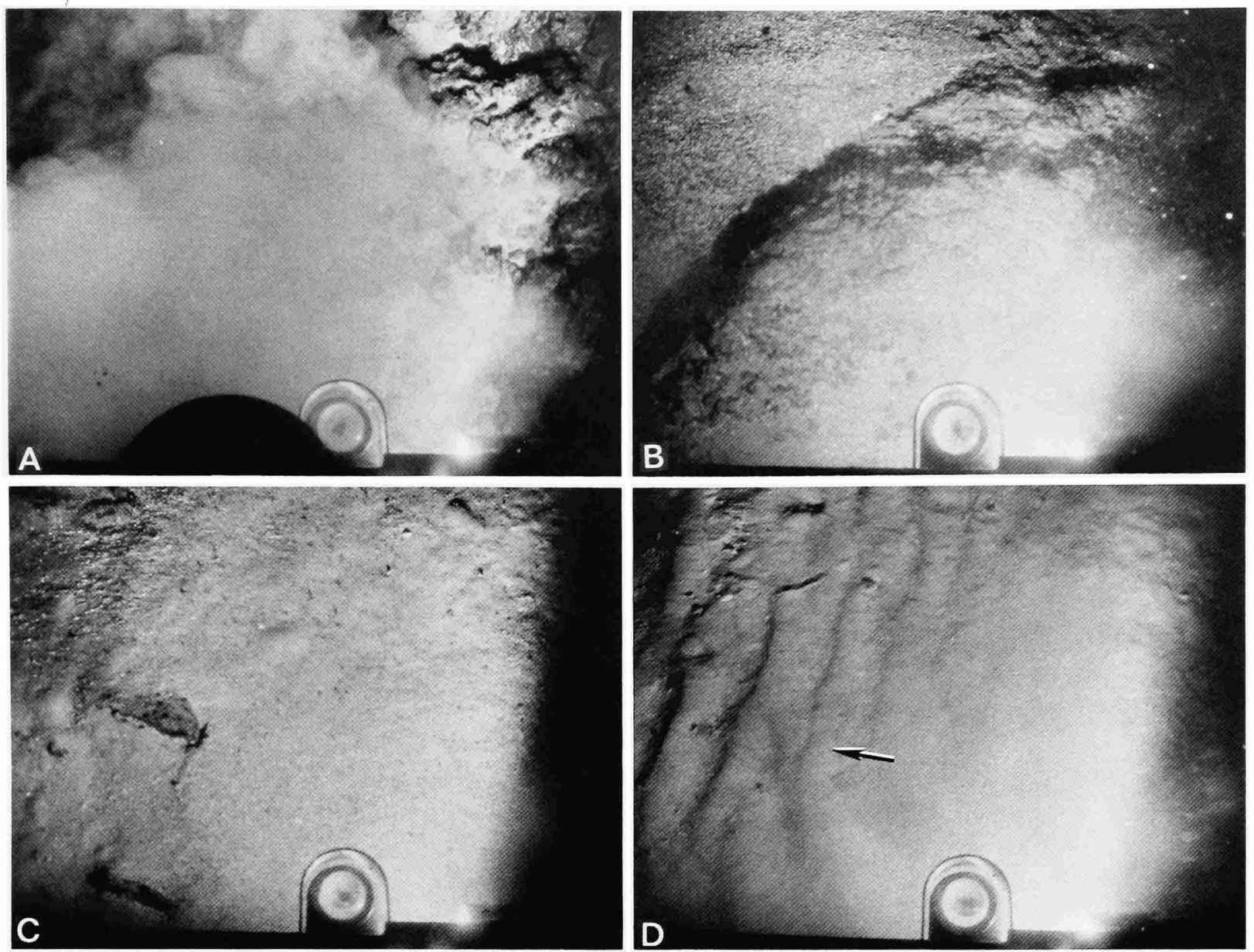

Figure 21.-Vema 26 camera station 7 vertical-view bottom photographs on the southern Congress peak (between 2815 and $2850 \mathrm{~m}$, location shown in Figure 2): A, B, volcanic pillows thinly covered by sediment mantle; c, very coarse biogenic-volcanigenic sediment and rock fragments; D, asymmetric ripples of muddy sand transported almost due north (arrow) (compass diameter $=7 \mathrm{~cm}$; photos courtesy of Lamont-Doherty Geological Observatory of Columbia University).

the oceans (Heezen and Tharp, 1968), which reveals a ubiquitous, highly variable vista dominated by positive topographic relief (ridges, fracture zones, abyssal hills, seamounts, knolls, etc., many shown on Figure 1) of predominantly volcanic origin.

It is pertinent with respect to the problem of proximal versus distal provenance that our study area is situated in the southermost section of the Sohm Abyssal Plain because (a) it has received a dominant proportion of its sediment fill by tur- bidity-current processes, with materials derived largely from the Canadian Maritime Provinces (Horn et al., 1971); (b) it underlies the region of densest suspended particulate matter, or nepheloid layer, concentration $\left(>3000 \mu \mathrm{g} / \mathrm{cm}^{2}\right)$ in the North Atlantic Ocean (Biscaye and Eittreim, 1977, fig. 5); (c) it is influenced by bottom-current activity (bottom photographs and seismic data, this study) resulting from large scale bottom-water circulation (Worthington, 1976; Laine, 1978); and (d) it lies near the geographic center of the 

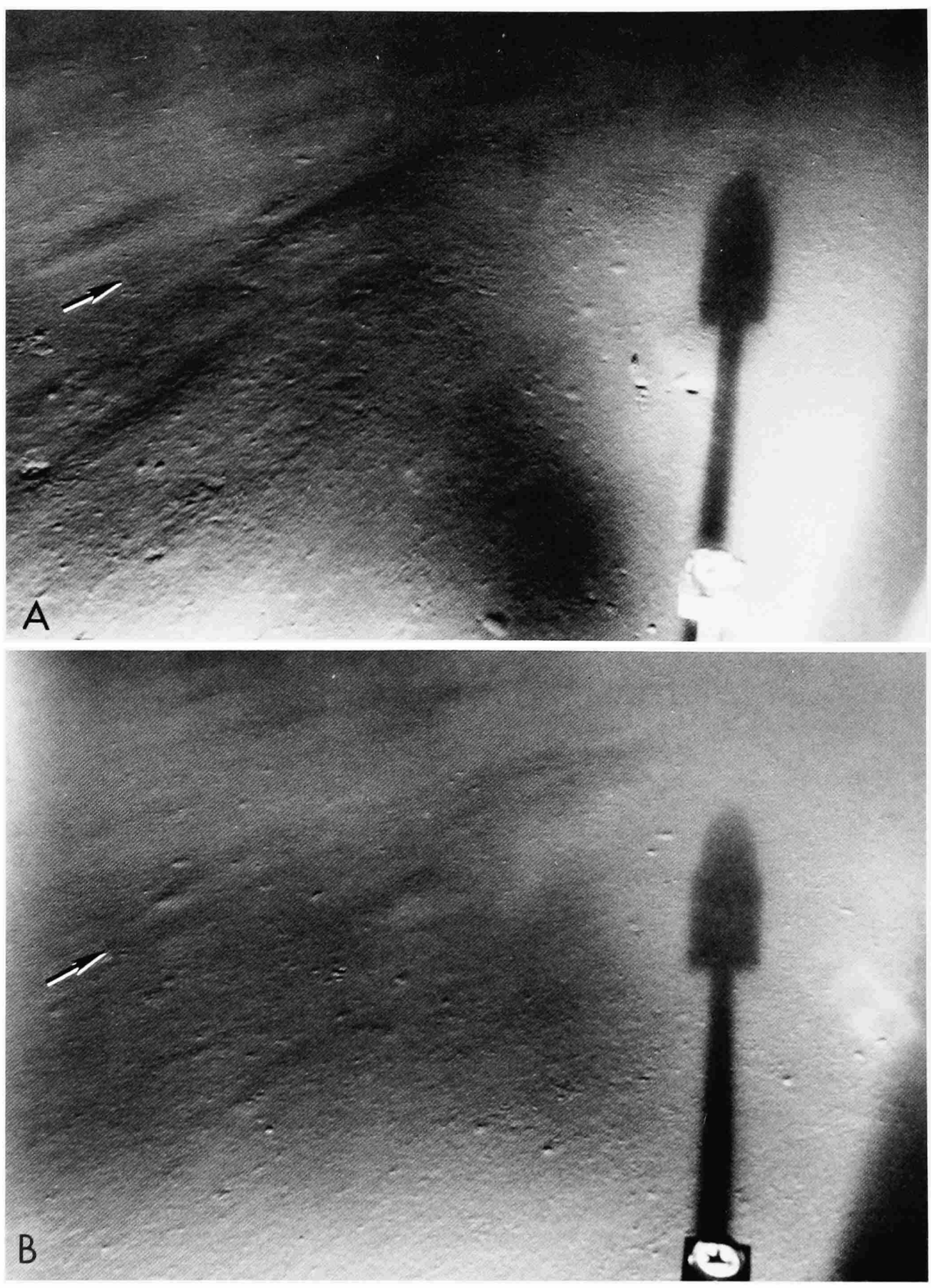

Figure 22.-Lynch 710-78 camera station 2, oblique-view bottom photographs on Sohm Abyssal Plain west of the southern Congress peak (about 5365 m, location shown in Figure 2): A and B reveal small craig-and-tail features and asymmetrically deformed mud structures oriented toward the northwest (arrows) (compass diameter $=6.3 \mathrm{~cm}$ ). 
Northwest Atlantic Basin, remote from land sources and almost completely surrounded by major volcanic features (including the lower flanking hills of the Mid-Atlantic Ridge, Bermuda Rise, and Kelvin and Corner Rise seamounts, see Figure 1 and also Ewing et al., 1973). Thus, the Southern Sohm Abyssal Plain is an appropriate area to evaluate the role of more proximal and volcanically derived sediments.

On a global scale, abyssal plain sediments consist of variable mixes of the following: (a) land and continental margin-derived clastics (including ice-rafted debris) and/or bioclastic materials; (b) suspensates of clastic (including wind-blown) and biogenic origin; (c) authigenic sediment and diagenetic products; and (d) volcanically derived materials. As in the case of most abyssal plains that have direct access to both land and continental margin-derived materials, the southern Sohm Plain piston cores reveal a dominant terrigenous fraction. This is best illustrated by core Atlantis 153-141. As in many other cores from this large abyssal plain, the significant proportion of terrigenous material was initially emplaced by turbidity current flows (Horn et al., 1971; Pilkey et al., 1980). All four Sohm Plain cores we examined also show an important pelagic component (e.g., core Vema 22-231) that is related to the well-defined distribution pattern of the suspension-rich, benthic nepheloid layer (Biscaye and Eittreim, 1977). Nevertheless, we have found that all cores have at least some silt- and even sandsize volcanic components (Tables 2-5). Despite the significant amounts of land-derived turbidite sediments that dominate abyssal plain cores $A t$ lantis 153 and Vema 22, significant amounts of volcanic materials, including palagonite and manganese micronodules, are present (Tables 2, 3).

The proportion of these volcanically derived products is related to the proximity of the cores to volcanic physiographic features of varying relief; see, for example, the large concentration of volcanic products near the top of core Vema 22231 (Table 3) and the position of this core relative to volcanic physiographic highs (Figure 4B). Our study clearly demonstrates that cores Vema 26-6 and -9 , from an area near the margins of the Sohm Plain bounded by abyssal hills and shielded from clastic land sources, contain a considerably enhanced fraction of volcanically related material of clay as well as silt and sand sizes (Table 4). These components include manganese micronodules, zeolites, palagonite, chlorophaeite, sideromelane, and smectite. Some of these materials are almost certainly supplied from the submarine weathering of basalt and its alteration products (Arrhenius, 1963; Nayudu, 1971; Honnorez, 1978; Scott et al., 1979; Furnes, 1980). We do not exclude the possibility that some of these components were derived from diagenetic remobilization (i.e., manganese micronodules, see Scott et al., 1979) and/or from distal land sources (smectite).

As a test of the true importance of this allochthonous volcanically derived component in the Sohm Abyssal Plain setting, we examined core Lynch 710-78-1, which was recovered from a sediment basin perched about $400 \mathrm{~m}$ above the abyssal plain on the flank of Congress Seamount (Figures 2, 7). About $500 \mathrm{~m}$ of sediment has accumulated in this elevated and isolated basin. The principal significance of the Lynch core location is that it is shielded from the direct influence of large-scale, bottom-hugging turbidity currents, which tend to follow along deeper contours of the abyssal plain.

From the Lynch seismic survey, it is apparent that distribution of the ponded sediment series is largely controlled by local topography and bottom-water flow. In this respect, the perched basin serves as a particularly valuable example (Figures $11,12)$. Most of the ponded sequence in this basin, while acoustically transparent to the sparker seismic frequency (about $100 \mathrm{~Hz}$ ), is in effect layered (Figure 13) when insonified with airgun frequencies (about $20 \mathrm{~Hz}$ ). Sections of core Lynch 710-78-1, from this pond, particularly the moderate- to reddish-brown layers (see horizons labeled 5YR4/4, Figure 14), provide evidence of pelagic deposition. The upper reddish-brown layer, deposited in post-Pleistocene time, and sim- 
ilar deeper horizons (Figure 14) are characterized by the following: (1) clay mineral assemblages of the type occurring throughout this North Atlantic region (Biscaye, 1965) but also including an enhanced fraction of montmorillonite; (2) an abundance of planktonic microfossils including foraminifera (often poorly preserved and recrystallized), radiolaria, and other siliceous microfossils whose proportions vary markedly vertically; (3) a very fine-grained texture (largely silty clay); (4) accumulation rates that for the most part are less than $3 \mathrm{~cm} / \mathrm{ka}$; (5) vague laminations and intensely bioturbated layers (Figure 15); and (6) the presence of siliceous agregates (Table 5) that may have been produced by benthic activity accompanying slow deposition, or may be of biogenic opaline derivation (T. C. Huang, pers. comm., 1980).

To help explain the above, we recall that the study area lies within the region of highest suspended particulate matter concentration in the North Atlantic Ocean (Biscaye and Eittreim, 1977). Moreover, Congress Seamount is located adjacent to a zone of marked bottom-current activity related to the westward-directed return flow of the southern Gulf Stream Gyre (cf. Worthington, 1976). Three bottom photograph stations (Figures 20-22) provide evidence for seafloor erosion, inferring flowing water on and around the seamount. Thus, the pelagic deposition in the perched basin is complicated by the interaction with moving bottom water in this region.

In addition to this pelagic transport regime, the marked cyclic nature of core Lynch 710-78-1 (Figure 14) shows that other modes also were responsible for deposition in this pond during the Quaternary. In comparison to the reddish-brown layers, the thicker, but somewhat less oxidized, yellowish-brown ooze layers (Figure 14, see horizons labeled 10YR4/2) have (a) somewhat larger proportions of better preserved planktonic foraminifera and calcareous nannofossils, and (b) tests of the latter, many of which are obviously reworked from older strata and dated from Pliocene to Upper Cretaceous (Figure 19); also, they (c) are coarser grained (clayey silt); (d) may display graded bedding (Figure 15, 303-280 cm); and (e) record much higher rates of accumulation (locally $13 \mathrm{~cm} / \mathrm{ka}$ ) in the Upper Pleistocene. Such layers probably account for some subdued, discontinuous reflectors noted on $3.5 \mathrm{kHz}$ profiles (Figure 10). Emplacement of this sediment type, particularly the graded beds, is almost certainly by gravitative mechanisms, including turbidity currents.

The ubiquitous, but irregular, abundance in this Lynch core of coarse silt- to sand-sized volcanic products, including primary (sideromelane, angular glass shards) components and secondary alteration derivatives (palagonite, chlorophaeite, zeolites), plus the importance of montmorillonite in the clay fraction indicate a steady, important supply of weathered material to the pond from an igneous source (Table 5). These products are associated, in some instances, with reworked microfossils as old as Upper Cretaceous (Figure 19). The proximity of the sediment pond to the seamount and other adjacent basement rises suggests that these igneous features are major-source terrains. In addition to this igneous supply, material reworked from the older depositional cover draping these basement rises also appears to serve as a sediment source (cf. Taylor and Hekinian, 1971). This volcanic-biogenic assemblage is similar to that described by Van Andel and Komar (1969), Nayudu (1971), and others. Bottom photographs show that currents on these bathymetric highs are capable of eroding and transporting weathered volcanic material along with microfossil-rich (pre-Quaternary to Recent) pelagic sediments and the recently deposited suspensates (Figure 20). This combined regime of suspensate deposition and reworking by bottom-current activity has resulted in accumulation of mixed biogenic-volcanigenic deposits on the seamount. These materials subsequently fail on the relatively steep slopes of the mount and adjacent highs and are resedimented to greater depths by a complex mechanism involving bottom current, creep and mass flow, including turbidity-current (cf. Stanley and Taylor, 1977). Specific examples of downslope displacement are provided by the graded 
foraminiferal sand bed (Figure 14, base at 303 $\mathrm{cm}$ ) and by the displacement of benthic foraminifera to a depth of at least $1000 \mathrm{~m}$ below their normal range as recorded in various layers of the Lynch core.

The perched sediment fill in the basin thus reveals a complex history of depositional processes: suspensates plus older locally derived pelagic deposits subsequently have been reworked by bottom currents and displaced downslope by gravitative mechanisms. Sediments derived from more distal sources supplement these ponded deposits in the perched basin. These latter distal materials would likely include resuspended Sohm Abyssal Plain sediments transported by bottom currents (Biscaye and Eittreim, 1977; Laine, 1978). Wind-blown silt, some of which may include a volcanic dust (cf. Huang et al., 1975, 1979; Sigurdsson et al., 1980), may also be a minor distal component. In addition, the measured accelerated rate of sedimentation in the Lynch core during the period from about 20,000 to 12,000 years B.P. (Figure 14) almost certainly records large-scale oceanographic phenomena that affected extensive parts of the North Atlantic during the late Pleistocene. These factors influencing the transport of material from distal sources to the southern Sohm Plain include eustatic oscillations coupled with important changes in the composition and circulation pattern of deep-water masses associated with the advances and retreats of polar fronts (Schnitker, 1974, 1979; CLIMAP project members, 1976; Ruddiman, 1977; Ruddiman and McIntyre, 1976, 1979; Duplessy et al., 1980; and others).

The perched sediment basin well illustrates a situation where there has been a concentration of an important contribution of volcanic-rich material emplaced by bottom-current erosion of the adjacent seamount and by coarse-grained mud flows, turbidity currents, and related submarine gravity flows. During a period of unknown duration, these mass flows resulted in the deposition of distinct volcaniclastic (possibly hyaloclastite) layers characterized by a distinct acoustic contrast, the internal reflectors (IR), within the sed- iment series (Figure 13). The areally restricted distribution of the internal reflectors in the depressions west and north of the northern Congress peak (Figure 12) also indicates a local derivation and a probable volcanic origin. While no direct evidence for the origin or nature of these reflectors is available, similar seismic reflection profiles showing large acoustic impedences have been drilled west of the study area (Tucholke and Vogt, 1979; Bowles, 1980). This drilling revealed volcaniclastic layers.

The IR acoustically "hard" layer can be traced almost uniformly across the perched basin (Figure 7, profile $\mathrm{J}-\mathrm{K}$ ); elsewhere around the Congress Seamount, the more restricted distribution of the internal reflectors is observed (Figure 9, profile A-B-C). The well-defined IR horizon is a smallscale example of an acoustic reflector comparable to the one covering a large area in the Northwest Atlantic Basin surrounding Bermuda, Horizon $\mathrm{A}^{\mathrm{v}}$ (Tucholke and Mountain, 1979; Bowles, 1980). The Worzel ash layer (Worzel, 1959) in the eastern Pacific, while having a subaerial explosive volcanic origin, also produces a similar seismic profiler record.

In general, the transport processes and resulting deposits that have accumulated in the Congress Seamount perched basin appear analogous to locally derived sediments revealed in and around other igneous regions, such as rises, ridges, seamounts, and rifts as illustrated by Heezen and Hollister (1971, their chapters 12 and 13). In particular, depressions in physiographically complex terrains tend to trap and concentrate locally derived sediments, including material from volcanic terrains and products of submarine weathering (Honnorez, 1978). An example includes the Nazca plate of the eastern Pacific (Heath and Dymond, 1977). In the northwest Atlantic, near the study area, are occurrences of volcanic-rich and mixed volcaniclastic and biogenic oozes concentrated in depressions within fracture zones and minor bathymetric lows on the Mid-Atlantic Ridge (Fox and Heezen, 1965; Siever and Kastner, 1967; Van Andel and Komar, 1969; Latouche and Parra, 1979; Scott et al., 1979). 


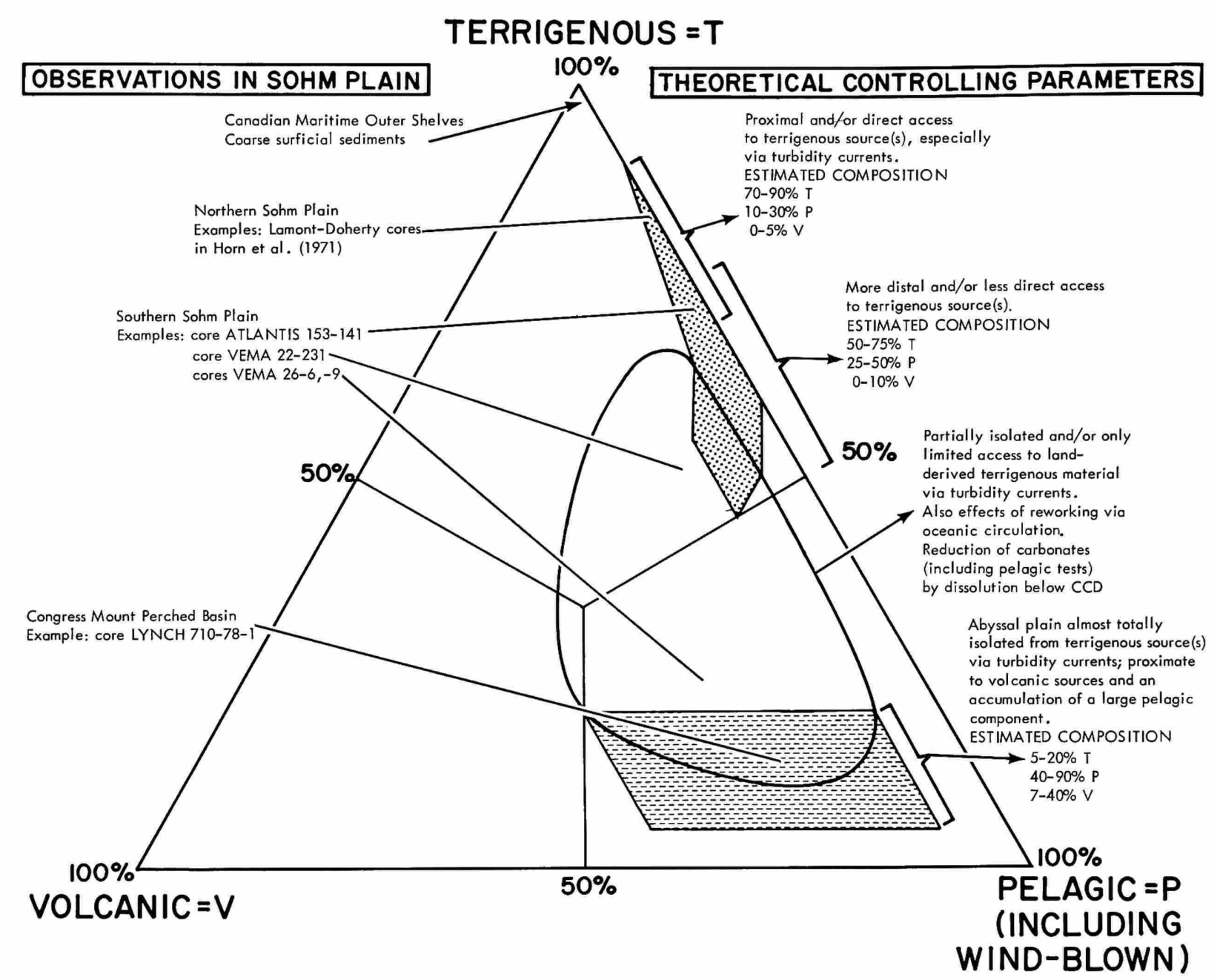

FIGURE 23.-Deposition model depicting different origins of sediment in the southern Sohm Abyssal Plain based on volumetric compositional analyses from this study. This scheme involves three major components: terrigenous (including bioclastic), pelagic (including wind-blown), and volcanic. This model indicates processes and is suggested to apply for abyssal plains in general.

Where topographic damming is absent on the eastern and southern flanks of Congress Seamount (Figure 12), such locally derived volcanic and reworked mixed volcaniclastic-biogenic materials are disseminated on the surrounding Sohm Abyssal Plain. In these instances, sediment provided from nearby volcanic topography is present, but in minor amounts, i.e., dispersed and masked within the reworked terrigeneous turbidite and biogenic suspensate sequences of the
Sohm Plain as illustrated by the Atlantis and Vema 22 cores (Tables 2, 3).

On the basis of the above, it is reasonable to expect that where the terrigenous supply is either blocked by positive or negative bathymetric features or markedly diminished (perhaps by distance from source), the proportion of pelagics and/or volcanics would be enhanced. To illustrate how volcanics can be used as an index or "yardstick" of modes of abyssal plain sedimenta- 
tion, a simple diagram is presented (Figure 23). This scheme uses a ternary diagram as a framework in order to illustrate the temporal or spatial sediment distribution. The three end-members of this triangle represent the major components of sedimentation: terrigenous, pelagic (including wind-blown), and volcanic materials (and their alteration products). Two distinct fields are recognized: one is dominated by terrigenous or terrigenous plus pelagic components; the other comprises largely pelagic or pelagic plus volcanic components. The former field (dot pattern on Figure 23) illustrates the masking of the pelagic and volcanic fraction by the preponderance of land-derived clastics in areas adjacent to land sources or along turbidity current paths. Thus, as distance increases or as access to land-derived sources diminishes, the proportion of the terrigenous component is decreased. In contrast, abyssal plain sediment accumulating in a region almost totally isolated from terrigenous sources would include primarily the pelagic and volcanic components (i.e., the latter field, dashed pattern in Figure 23).

This simplified pattern in the Sohm Abyssal Plain is complicated by dynamic factors such as fluctuations of large-scale bottom-water circulation and the variability of the depth at which the dissolution of carbonate (CCD) occurs (e.g., Jansa et al., 1979; Thiede et al., 1980; and others). These factors would explain downcore variability in carbonate test content and the significant areal variation in sediment rates observed in, and adjacent to, this study area. These physical oceanographic conditions result in the blurring of the distinction between the two major fields as depicted by the closed curve in Figure 23. There are obviously many possible ways in which these factors would apply. For example, moving bottom waters can winnow and/or transport locally derived volcanics (cf. Huang, 1980) and older weathered sediments to areas remote from their provenance. In another case, increased rates of carbonate dissolution (due to changes in the CCD) could reduce the numbers of preserved calcareous pelagic tests, thus markedly enhancing the proportion of siliceous pelagic tests, debris, and terrigenous and/or volcanic components. These phenomena might explain the high volcanic content in some abyssal plains, and illustrations of this on a more regional scale have been presented (Heath and Dymond, 1977). It would also help account for vertical lithofacies variations noted in the cores we examined, particularly Lynch-1.

This diagram (Figure 23), which models abyssal plain sedimentation, is largely idealized, and based on general concepts. We have indicated the approximate location of the southern Sohm Abyssal Plain cores on the theoretical plot. It is noted that even in an abyssal plain such as the Sohm, which has had ample and direct access to abundant terrigenous sources, particularly during the Pliocene and Quaternary, the volcanic fraction is significant. Although not dominant, this fraction may constitute as much as 1 percent, and locally up to 5 percent, of the total sediment fill. These values are modest when compared to the proportion of volcaniclastic sediments in regions close to volcanic arcs (Sigurdsson et al., 1980).

We predict that further detailed petrographic examination of cores collected in the Sohm and other abyssal plains will reveal that locally derived reworked material of both sedimentary and volcanic origin may account for a significant fraction of the total sediment fill of abyssal areas. 


\section{Appendix}

Tables

TABLE 1.-Grain-size analyses from selected samples of cores studied, showing percentages of sand $(>63 \mu \mathrm{m})$, silt, and clay $(<2 \mu \mathrm{m})$ and also the silt/clay ratio $(\mathrm{T}=$ trace; dashed lines $=$ not processed)

\begin{tabular}{|c|c|c|c|c|c|c|c|c|c|}
\hline $\begin{array}{l}\text { Sample } \\
\text { depth }(\mathrm{cm})\end{array}$ & $\begin{array}{c}\% \\
\text { sand }\end{array}$ & $\begin{array}{r}\% \\
\text { silt }\end{array}$ & $\begin{array}{c}\% \\
\text { clay }\end{array}$ & $\begin{array}{c}\text { silt/clay } \\
\text { ratio }\end{array}$ & $\begin{array}{l}\text { Sample } \\
\text { depth }(\mathrm{cm})\end{array}$ & $\begin{array}{c}\% \\
\text { sand }\end{array}$ & $\begin{array}{l}\% \\
\text { silt }\end{array}$ & $\begin{array}{c}\% \\
\text { clay }\end{array}$ & $\begin{array}{c}\text { silt/clay } \\
\text { ratio }\end{array}$ \\
\hline \multicolumn{5}{|c|}{ ATLANTIS core $|53-| 4 \mid$} & \multicolumn{5}{|c|}{ VEMA core $26-6$} \\
\hline $7-8$ & T & 50 & 50 & 1.00 & $2-3$ & 4 & 35 & 61 & 0.57 \\
\hline $49-50$ & T & 77 & 23 & 3.34 & $29-32$ & T & 34 & 66 & 0.51 \\
\hline $109-110$ & T & 62 & 38 & 1.63 & $45-47$ & $T$ & 29 & 71 & 0.40 \\
\hline $172-173$ & T & 32 & 68 & 0.47 & $124-126$ & $T$ & 25 & 75 & 0.33 \\
\hline $2|2-2| 3$ & $T$ & 35 & 65 & 0.53 & $227-229$ & $T$ & 20 & 80 & 0.25 \\
\hline $240-241$ & T & 31 & 69 & 0.44 & $272-274$ & $T$ & 21 & 79 & 0.26 \\
\hline $265-266$ & T & 88 & 12 & 7.33 & $321-323$ & 1 & 19 & 80 & 0.23 \\
\hline $327-328$ & $T$ & 38 & 62 & 0.61 & $344-346$ & 3 & 27 & 70 & 0.38 \\
\hline $384-385$ & 5 & 78 & 17 & 4.58 & $393-395$ & T & 17 & 83 & 0.20 \\
\hline $400-401$ & 56 & 34 & 10 & 3.40 & $474-476$ & $T$ & 27 & 73 & 0.36 \\
\hline $465-466$ & 68 & 26 & 6 & 4.33 & $544-546$ & $T$ & 18 & 82 & 0.21 \\
\hline $500-50 \mathrm{l}$ & 67 & 24 & 9 & 2.66 & & & & & \\
\hline $575-580$ & 67 & 26 & 7 & 3.71 & \multicolumn{5}{|c|}{ VEMA core $26-9$} \\
\hline 660.661 & 24 & 37 & 39 & 0.94 & & & & & \\
\hline $720-721$ & 51 & 31 & 18 & 1.72 & $1-3$ & $T$ & 34 & 66 & 0.51 \\
\hline $745-746$ & 36 & 37 & 27 & 1.37 & $44-46$ & $T$ & 34 & 66 & 0.51 \\
\hline $807-809$ & 65 & 28 & 7 & 4.00 & $51-53$ & $T$ & 30 & 70 & 0.42 \\
\hline $923-924$ & 65 & 27 & 8 & 3.37 & $159-161$ & $T$ & 14 & 86 & 0.16 \\
\hline $985-986$ & 67 & 33 & $T$ & $>33.0$ & $225-227$ & T & 14 & 86 & 0.16 \\
\hline & & & & & $280-282$ & $T$ & 14 & 86 & 0.16 \\
\hline \multirow{2}{*}{\multicolumn{5}{|c|}{ VEMA core $22-231$}} & $407-409$ & $T$ & 14 & 86 & 0.16 \\
\hline & & & & & $435-437$ & $T$ & 14 & 86 & 0.16 \\
\hline $0-2$ & $T$ & 37 & 68 & 0.54 & $503-505$ & $T$ & 14 & 86 & 0.16 \\
\hline $11-13$ & 2 & 35 & 65 & 0.53 & \multirow{2}{*}{\multicolumn{3}{|c|}{$\begin{array}{lll}593-595 & T & 13\end{array}$}} & \multirow[t]{2}{*}{87} & \multirow[t]{2}{*}{0.14} \\
\hline $85-87$ & T & 36 & 64 & 0.56 & & & & & \\
\hline $122-123$ & T & 30 & 70 & 0.52 & \multicolumn{5}{|c|}{ LYNCH core $710-78-1$} \\
\hline $168-170$ & T & 28 & 72 & 0.38 & & & & & \\
\hline $245-247$ & T & 36 & 64 & 0.56 & $13-15$ & 2 & 42 & 56 & 0.75 \\
\hline $253-255$ & T & 37 & 63 & 0.58 & $34-36$ & $T$ & 35 & 65 & 0.53 \\
\hline $401-403$ & T & 72 & 28 & 2.57 & $80-82$ & T & 37 & 63 & 0.58 \\
\hline $498-500$ & T & 60 & 40 & 1.50 & $195-197$ & $\mathrm{~T}$ & 52 & 48 & 1.08 \\
\hline $672-673$ & T & 38 & 62 & 0.61 & $225-227$ & $\mathrm{~T}$ & 73 & 27 & 2.70 \\
\hline $681-683$ & T & 48 & 52 & 0.92 & $297-299$ & 4 & -- & -- & -- \\
\hline $913-915$ & T & 49 & 51 & 0.96 & $299-301$ & 10 & -- & -- & -- \\
\hline $927-929$ & $T$ & 46 & 54 & 0.85 & $301-303$ & 50 & 25 & 25 & 1.0 \\
\hline $1050-1052$ & T & 58 & 42 & 1.38 & $304-306$ & 3 & -- & -- & -- \\
\hline $122 \mid-1223$ & $T$ & 73 & 27 & 2.70 & $345-347$ & $T$ & 42 & 58 & 0.72 \\
\hline $1236-1237$ & $T$ & 51 & 49 & 1.04 & $372-375$ & 1 & 55 & 44 & 1.25 \\
\hline $1304-1305$ & 42 & 40 & 18 & 2.22 & $434-436$ & $T$ & 32 & 68 & 0.47 \\
\hline |353-|354 & $T$ & 78 & 22 & 3.54 & $443-445$ & $T$ & 72 & 28 & 2.57 \\
\hline$|460-| 462$ & $T$ & 37 & 63 & 0.58 & $542-544$ & 1 & 46 & 55 & 0.83 \\
\hline$|480-| 48 \mid$ & $T$ & 62 & 38 & 1.63 & $557-559$ & 3 & 51 & 46 & 1.10 \\
\hline
\end{tabular}


TABLE 2.-Summary of results of grain-size and compositional analyses of core Atlantis 153-141, depth $5350 \mathrm{~m}$

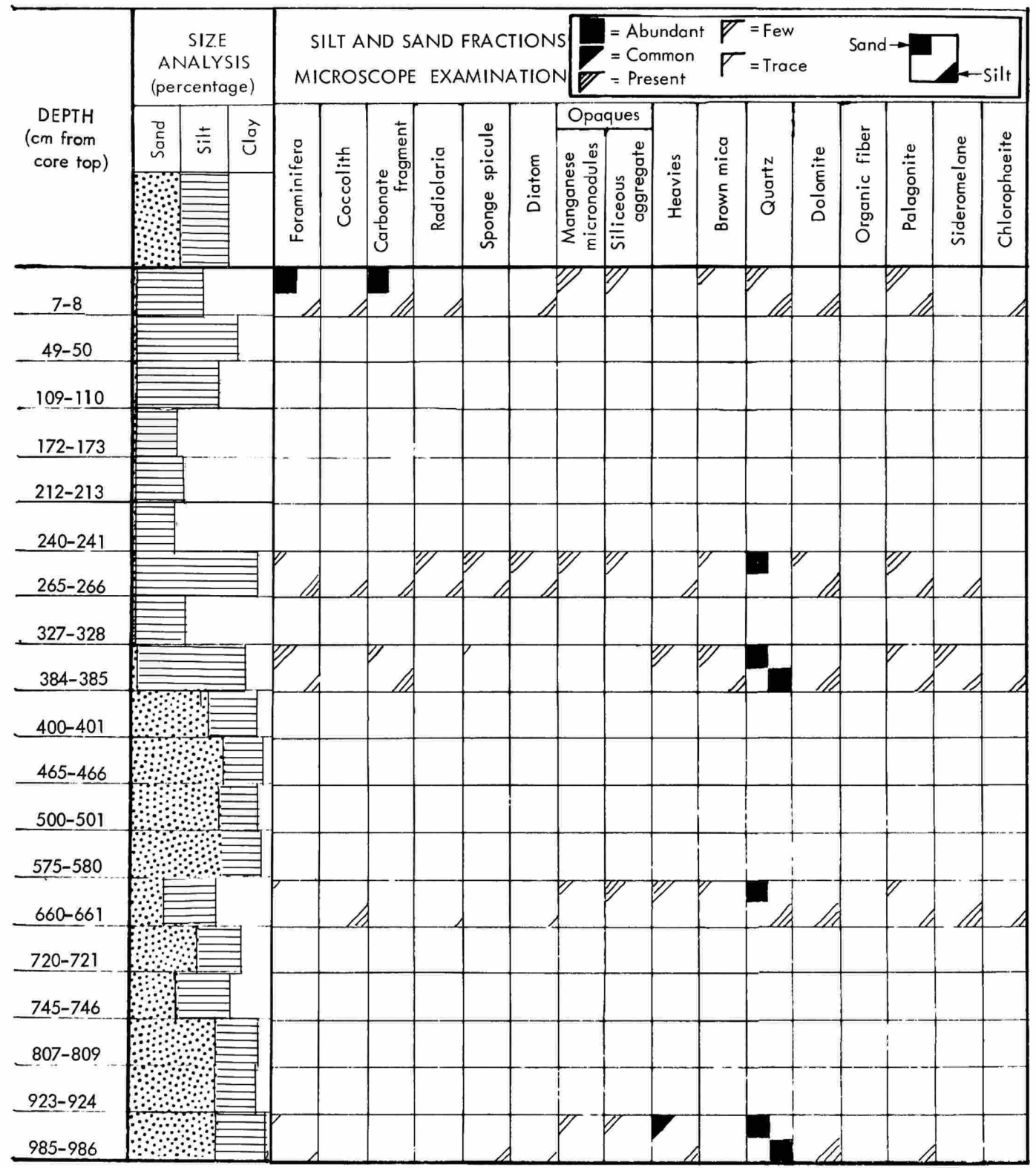


TABLE 2.-Continued

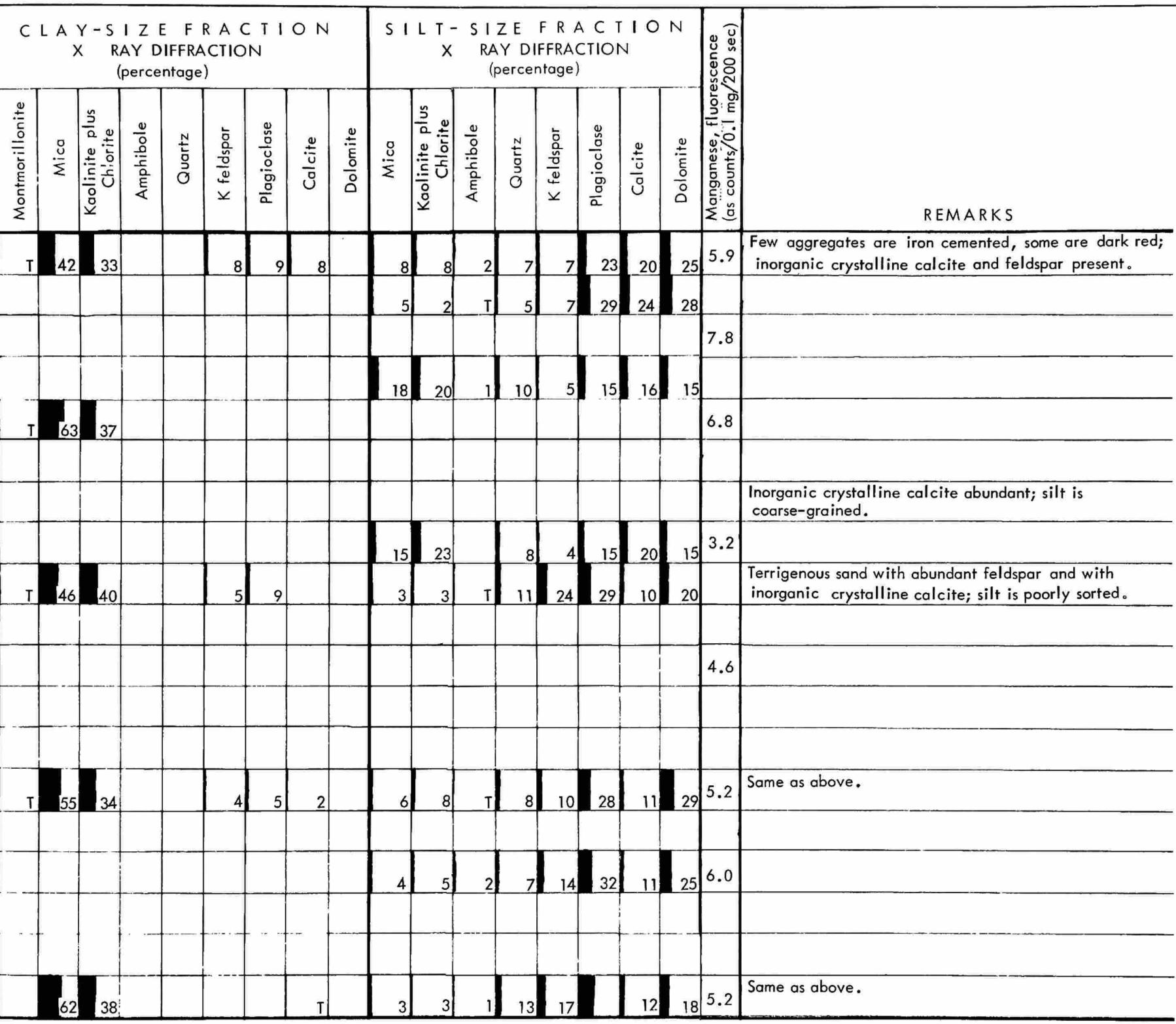


TABLE 3.-Summary of results of grain-size and compositional analyses of core Vema 22-231, depth $5535 \mathrm{~m}$

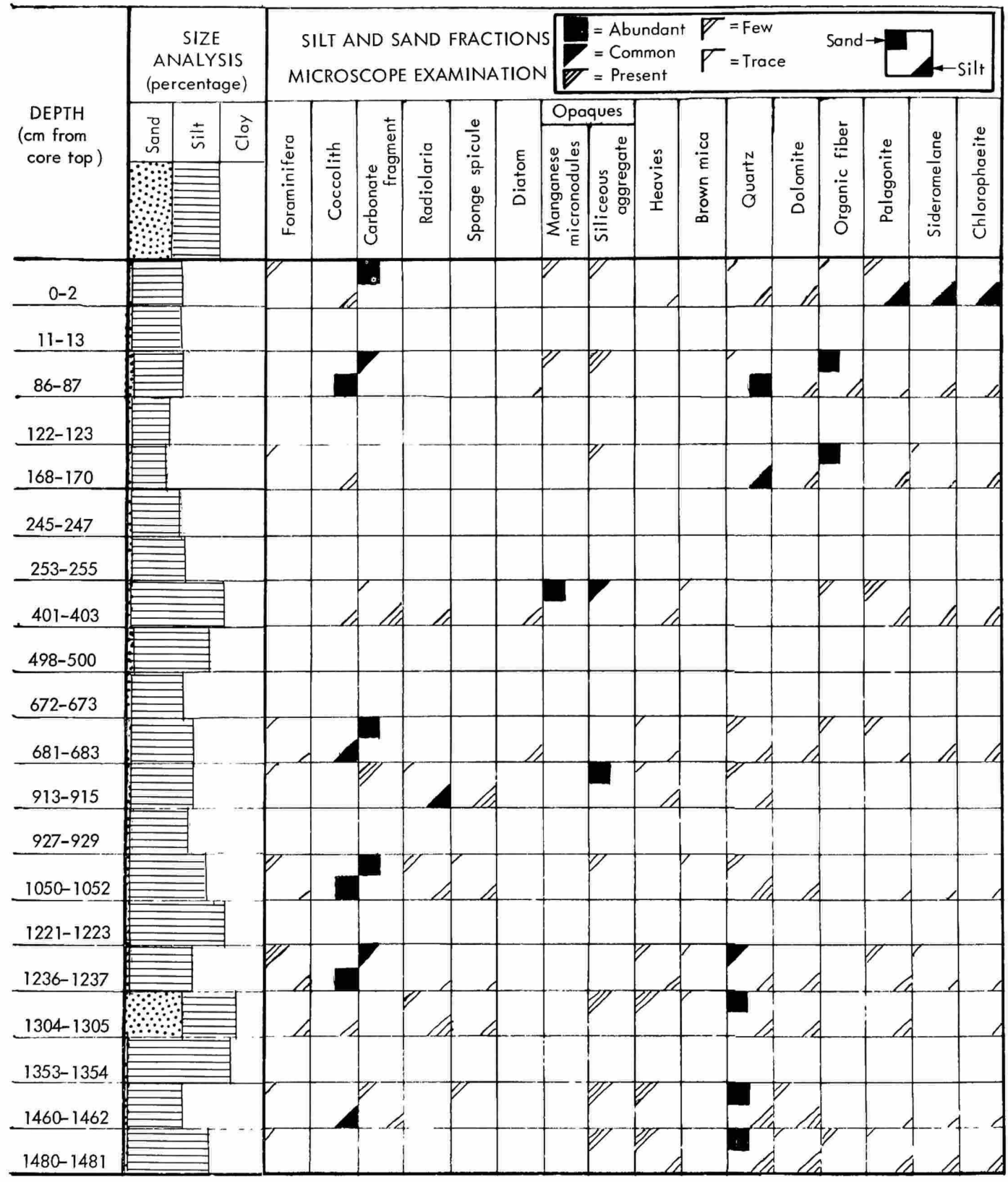


TABLE 3.-Continued

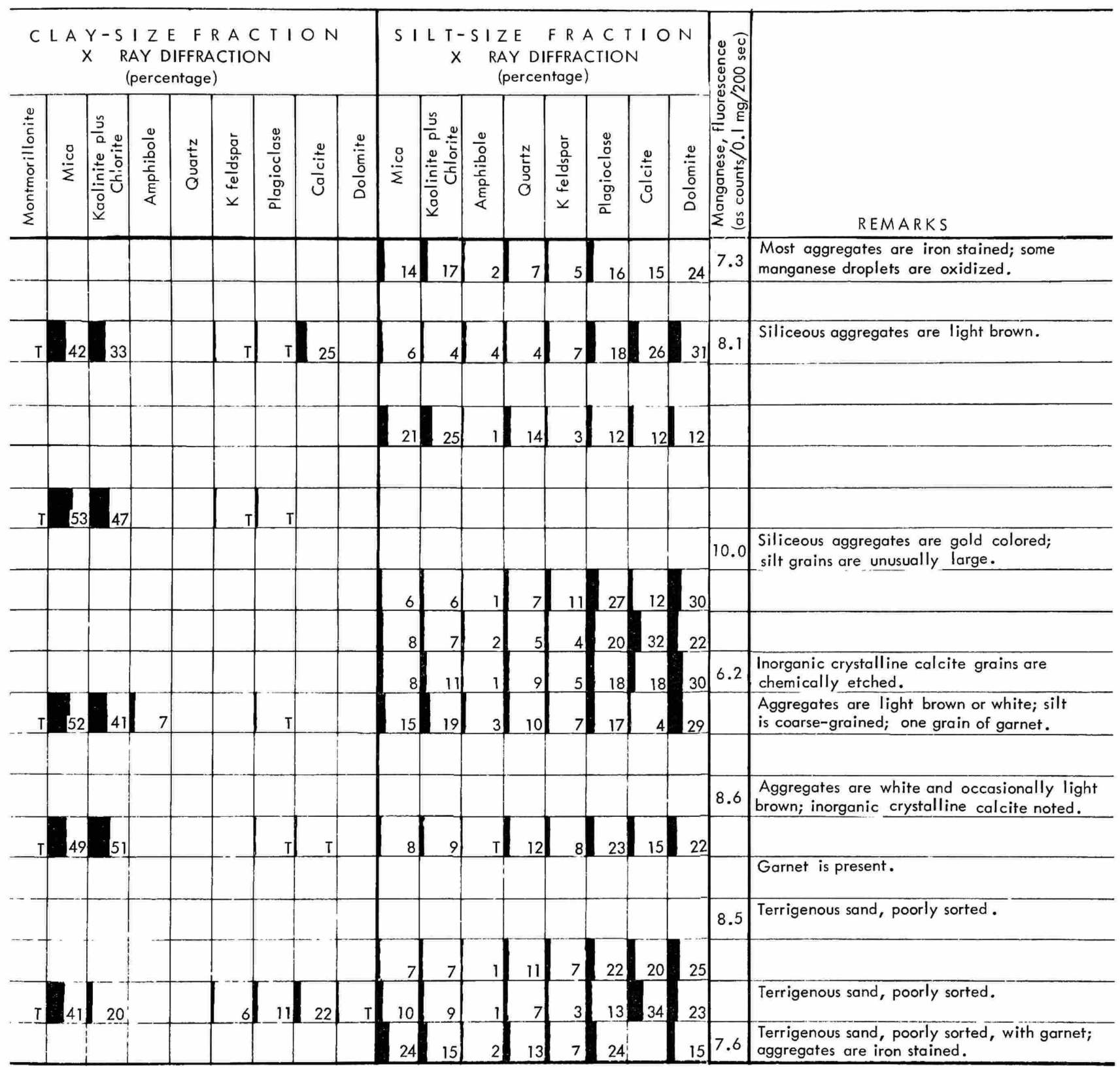


TABLE 4.--Summary of results of grain-size and compositional analyses of cores Vema 26-6, depth $5207 \mathrm{~m}$, and 26-9, depth $5546 \mathrm{~m}$

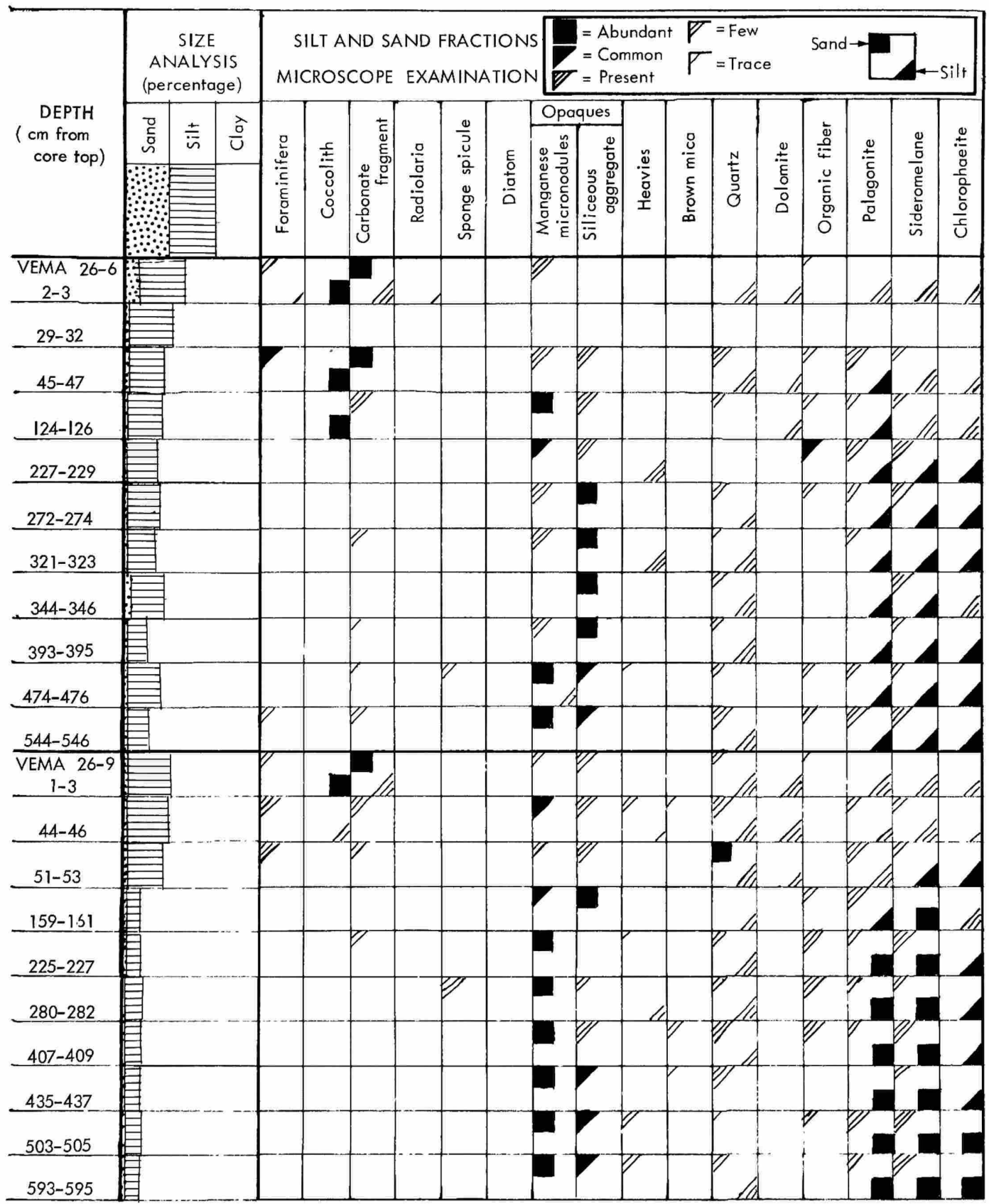


TABle 4.-Continued

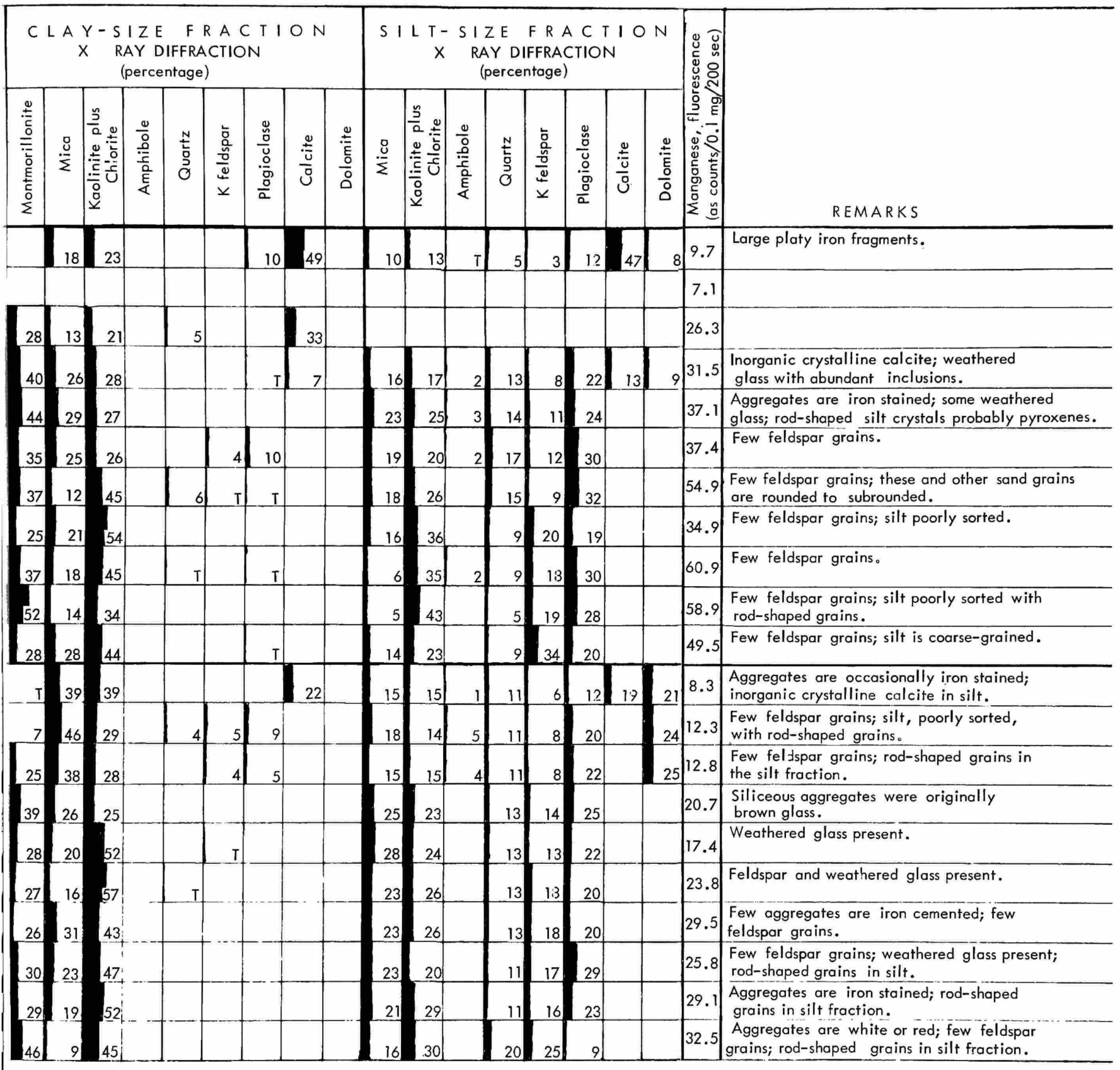


TABLE 5.-Summary of results of grain-size and compositional analyses of core Lynch 710-78-1, depth $5207 \mathrm{~m}$

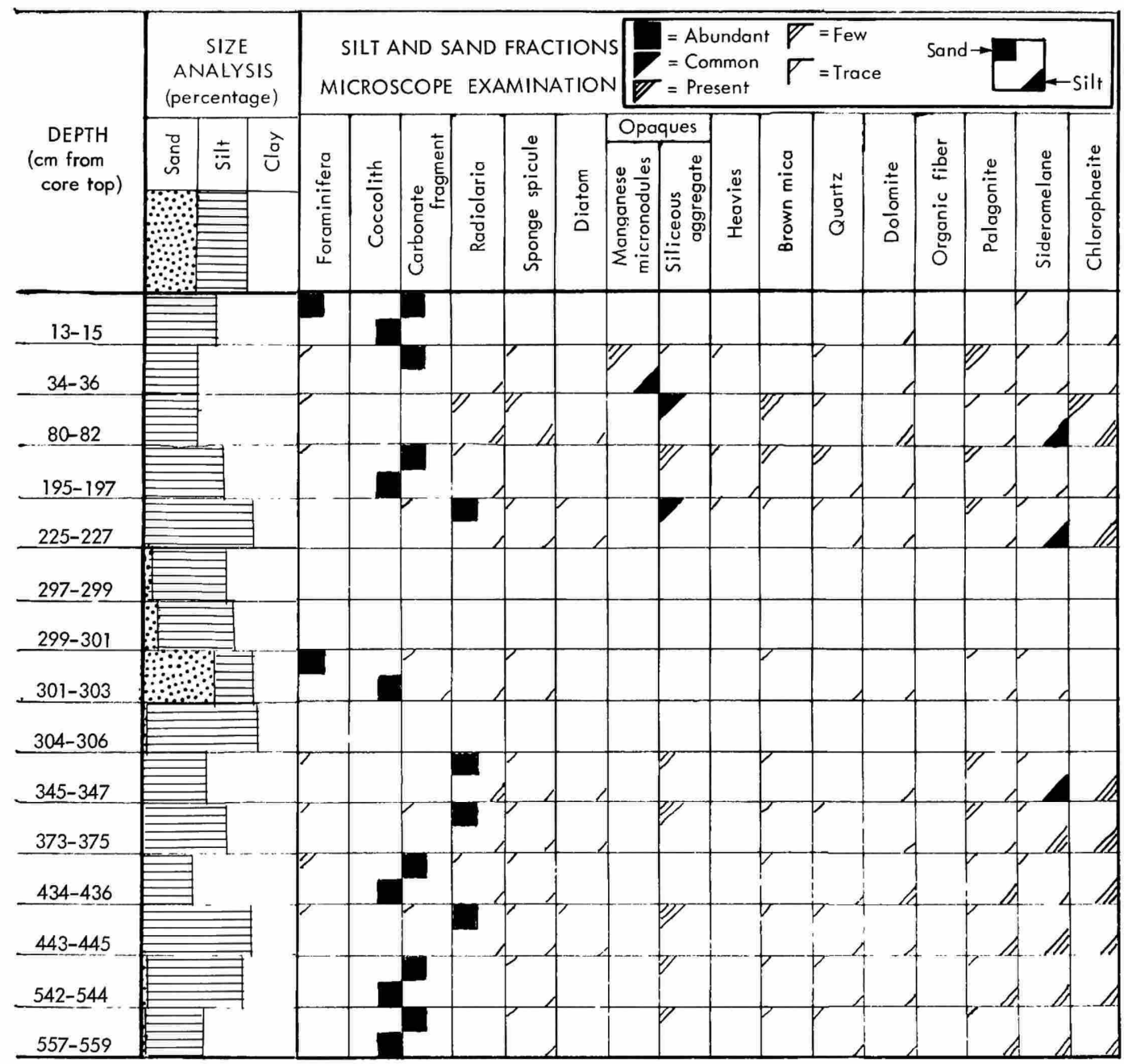


TABLE 5.-Continued

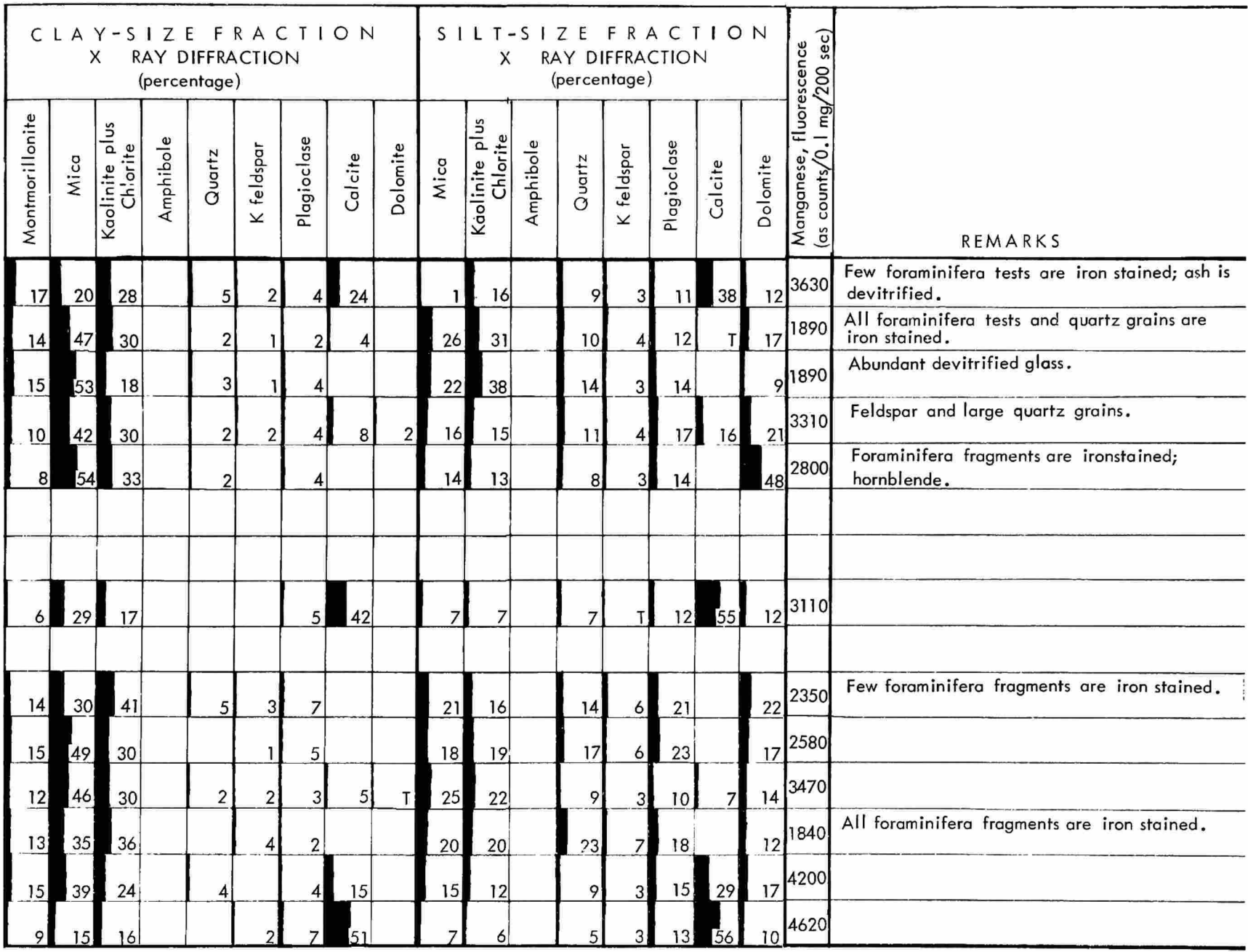




\section{Literature Cited}

Amos, A. F., and R. D. Gerard

1979. Anomalous Bottom Water South of the Grand Banks Suggests Turbidity Current Activity. Science, 203:894-897.

Arrhenius, G.

1963. Pelagic Sediments. In M. N. Hill, editor, The Sea, 3:655-727. London: Interscience Publishers.

Biscaye, P. E.

1965. Mineralogy and Sedimentation of Recent DeepSea Clay in the Atlantic Ocean and Adjacent Seas and Oceans. Geological Society of America Bulletin, 76: 803-832.

Biscaye, P. E., and S. E. Eittreim

1977. Suspended Particulate Loads and Transports in the Nepheloid Layer on the Abyssal Atlantic Ocean. Marine Geology, 23:155-172.

Bowles, F. A.

1980. Stratigraphy and Sedimentation of the Archipelagic Apron and Adjoining Area Southeast of Bermuda. Marine Geology, 37:267-294.

Brown, N. L.

1974. A Precision CTD Microprofiler. Institute of Electrical and Electronic Engineers International Conference on Engineering in the Ocean Environment, 2:270-278.

CLIMAP project members

1976. The Surface of the Ice-Age Earth. Science, 191: 1131-1137.

Duplessy, J.-C., J. Moyers, and C. Pujol

1980. Deep Water Formation in the North Atlantic Ocean during the Last Ice Age. Nature, 286:479482.

Ericson, D. B., M. Ewing, G. Wollin, and B. C. Heezen

1961. Atlantic Deep-Sea Sediment Cores. Geological Society of America Bulletin, 72:193-286.

Ewing, J., M. Ewing, C. Windisch, and T. Aiken

1974. Seismic Reflection Profiles. In Underway Marine Geophysical Data in the North Atlantic-June 1961January 1971, part E. Palisades, New York: Lamont-Doherty Geological Observatory of Columbia University.

Ewing, M., G. Carpenter, C. Windisch, and J. Ewing

1973. Sediment Distribution in the Oceans: The Atlantic. Geological Society of America Bulletin, 84:71-88.

Fox, P. J., A. M. Harrian, B. C. Heezen, W. Prell, and W.B.F. Ryan

1967. Contour Currents and Their Effect on the Distribution of Sediment on the Northern Bermuda
Rise [Abstract]. Program of the Annual Meeting in New Orleans, Geological Society of America, 1967:7071.

Fox, P. J., and B. C. Heezen

1965. Sands of the Mid-Atlantic Ridge. Science, 149: 1367-1370.

Furnes, $\mathrm{H}$.

1980. Chemical Changes during Palagonitization of an Alkaline Olivine Basaltic Hyaloclastite, Santa Maria, Azores. Neues Jahrbuch für Mineralogie, 138: 14-30.

Heath, G. R., and J. Dymond

1977. Genesis and Transformation of Metalliferous Sediments from the East Pacific Rise, Bauer Deep, and Central Basin, Northwest Nazca Plate. Geological Society of America Bulletin, 88:723-733.

Heezen, B. C.

1963. Turbidity Currents. In M. N. Hill, editor, The Sea, 3:742-775. London: Interscience Publishers.

Heezen, B. C., and M. Ewing

1952. Turbidity Currents and Submarine Slumps and the Grand Banks Earthquake. American Journal of Science, 250:849-873.

Heezen, B. C., and C. D. Hollister

1971. The Face of the Deep. 659 pages, illustrated. New York: Oxford University Press.

Heezen, B. C., and A. S. Laughton

1963. Abyssal Plains. In M. N. Hill, editor, The Sea, 3: 312-364. London: Interscience Publishers.

Heezen, B. C., and M. Tharp

1968. The Floor of the Oceans [chart]. New York: Geological Society of America.

Heezen, B. C., M. Tharp, and M. Ewing

1959. The Floors of the Oceans - the North Atlantic. Geological Society of America Special Paper, 65: 122 pages.

Honnorez, J

1978. Generation of Phillipsites by Palagonitization of Basaltic Glass in Sea Water and the Origin of Krich Deep-Sea Sediments. In L. B. Sand and F. A. Mumpton, editors, Natural Zeolites: Occurrence, Properties, Use, pages 245-258. Oxford: Pergamon Press.

Horn, D. R., M. Ewing, B. M. Horn, and M. N. Delach 1971. Turbidites of the Hatteras and Sohm Abyssal Plains, Western North Atlantic. Marine Geology, 11: 287-323. 
Houtz, R. E.

1974. Preliminary Study of Global Sediment Sound Velocities from Sonobouy Data. In L. Hampton, editor, Physics of Sound in Marine Sediments, pages 519-534. New York: Plenum Publishing Corporation.

Huang, T. C.

1980. A Volcanic Sedimentation Model: Implications of Processes and Responses of Deep-Sea Ashes. Marine Geology, 38:103-122.

Huang, T. C., N. D. Watkins, and D. M. Shaw

1975. Atmospherically Transported Volcanic Glass in Deep-Sea Sediments: Development of a Separation and Counting Technique. Deep Sea Research, 22: 185-196.

Huang, T. C., N. D. Watkins, and L. Wilson

1979. Deep-Sea Tephra from the Azores during the Past 300,000 Years: Eruptive Cloud Height and Ash Volume Estimates. Geological Society of America Bulletin, 90:235-288.

Hubert, J. F.

1964. Textural Evidence for Deposition of Many Western North Atlantic Deep-Sea Sands by OceanBottom Currents Rather Than Turbidity Currents. The Journal of Geology, 72:757-785.

Jansa, L. F., P. Enos, B. E. Tucholke, F. M. Gradstein, and R. E. Sheridan

1979. Mesozoic-Cenozoic Sedimentary Formation of the North American Basin; Western North Atlantic. In M. Talwani, W. Hay, and W.B.F. Ryan, editors, Deep Drilling Results in the Atlantic Ocean: Continental Margins and Paleoenvironment. Maurice Ewing Series, 3:3-57. Washington: American Geophysical Union.

Laine, E. P.

1978. Geological Effects of the Gulf Stream System in the North American Basin. 164 pages. Doctoral dissertation, Woods Hole Oceanographic Institution-MIT.

Laine, E. P., and C. D. Hollister

1981. Geological Effects of the Gulf Stream System on the Northern Bermuda Rise. Marine Geology, 39: 277-310.

LaTouche, C., and M. Parra

1979. La Sédimentation au Quaternaire Recent dans le "Northwest Atlantic Mid-Ocean Canyon"-Apport des données minéralogiques et géochimiques. Marine Geology, 29:137-164.

Nayudu, Y. R.

1971. Geologic Implications of Microfossils in Submarine Volcanics. Bulletin Volcanologique, 35:402-423.

Peacock, M., and R. Fuller

1928. Chlorophaeite, Sideromelane and Palagonite from the Columbia River Plateau. The American Minerologist, 13:360-382.

Peterson, M.N.A., N. T. Edgar, C. van der Borch, M. B. Cita, S. Gartner, Jr., R. Goll, and C. Nigrini

1970. Site 9. In M.N.A. Peterson, N. T. Edgar, M. B. Cita, S. Gartner, Jr., R. Goll, and C. van der Borch, editors, Initial Reports of the Deep Sea Drilling Project, 2:35-116. Washington: U.S. Government Printing Office.

Pilkey, O. H., S. D. Locker, and W. J. Cleary

1980. Comparison of Sand Layer Geometry on Flat Floors of 10 Modern Depositional Basins. The American Association of Petroleum Geologists Bulletin, 64:841-856.

Ruddiman, W. F.

1977. North Atlantic Ice Rafting: A Major Change at 75,000 Years before the Present. Science, 196:12081210.

Ruddiman, W. F., and A. McIntyre

1976. Northeast Atlantic Paleoclimatic Changes over the Past 600,000 Years. Geological Society of America Memoir, 145:111-146. Boulder, Colorado: Geological Society of America.

1979. Warmth of the Subpolar North Atlantic Ocean during Northern Hemisphere Ice-Sheet Growth. Science, 204:173-175.

Schmitz, W. J., Jr.

1977. On the Deep General Circulation in the Western North Atlantic. Journal Marine Research, 35:21-28.

Schnitker, D.

1974. West Atlantic Abyssal Circulation during the Past 120,000 Years. Nature, 248:385-387.

1979. The Deep Waters of the Western North Atlantic during the Past 24,000 Years, and the Re-initiation of the Western Boundary Undercurrent. $\mathrm{Ma}$ rine Micropaleontology, 4:265-280.

Scott, M. R., P. F. Salter, and L. A. Barnard

1979. Chemistry of Ridge-Crest Sediments from the Northern Atlantic Ocean. In M. Talwani, C. G. A. Harrison, and D. E. Hayes, editors, Deep Drilling Results in the Atlantic Ocean: Ocean Crust. Maurice Ewing Series, 2:403-428. Washington: American Geophysical Union.

Siever, R., and M. Kastner

1967. Mineralogy and Petrology of Some Mid-Atlantic Ridge Sediments. Journal of Marine Research, 25: 263-287.

Sigurdsson, H., R.S.J. Sparks, S. N. Carey, and T. C. Huang 1980. Volcanogenic Sedimentation in the Lesser Antilles Arc. Journal of Geology, 88:523-540.

Silva, A. J., C. D. Hollister, E. P. Laine, and B. E. Beverly 1976. Geotechnical Properties of Deep-Sea Sediments: Bermuda Rise. Marine Geotechnology, 1:195-232. 
Stanley, D. J., and P. T. Taylor

1977. Sediment Transport down a Seamount Flank by a Combined Current and Gravity Process. Marine Geology, 23:77-88.

Stonecipher, S.

1978. Chemistry and Deep-Sea Phillipsite, Clinoptilolite, and Host Sediments. In L. B. Sand and F. A. Mumpton, editors, Natural Zeolites: Occurrence, Properties, Use, pages 221-234. Oxford: Pergamon Press.

Taylor, P. T, and R. Hekinian

1971. Geology of a Newly Discovered Seamount in the New England Seamount Chain. Earth and Planetary Science Letters, 11:73-82.

Thiede, J., T. Agdestein, and J. E. Strand

1980. Depth Distribution of Calcareous Sediments in the Mesozoic and Cenozoic North Atlantic Ocean. Earth and Planetary Science Letters, 47:416-422.

Tucholke, B. E., and G. S. Mountain

1979. Seismic Stratigraphy, Lithostratigraphy and $\mathrm{Pa}-$ leosedimentation Patterns in the North American Basin. In M. Talwani, C.G.A. Harrison, and D. E. Hayes, editors, Deep Drilling Results in the Atlantic Ocean: Ocean Crust. Maurice Ewing Series, 2: 58-86. Washington: American Geophysical Union.
Tucholke, B. E., and P. R. Vogt

1979. Site 382: Nashville Seamount-Volcanism along the Eastern New England Seamount Chain. In B. E. Tucholke, P. R. Vogt, I. O. Murdmaa, P. Rothe, R. L. Houghton, J. S. Galehouse, A. Kaneps, C. L. McNulty, Jr., H. Okada, J. W. Kendrick, K. R. Demars, and I. N. McCave, editors, Initial Reports of the Deep-Sea Drilling Project, 43:3193. Washington: U.S. Government Printing Office.

Van Andel, T. H., and P. D. Komar

1969. Ponded Sediments of the Mid-Atlantic Ridge between $22^{\circ}$ and $23^{\circ}$ North Latitude. Geological Society of America Bulletin, 80:1163-1190.

Worthington, L. V.

1976. On the North Atlantic Circulation. Johns Hopkins Oceanographic Studies, 6: 110 pages. Baltimore: Johns Hopkins University Press.

Worzel, J. L.

1959. Extensive Deep Sea Subbottom Reflections Identified as White Ash. Proceedings of the National Academy of Science, 45:349-355.

Wüst, G

1949. Blockdiagrame der Atlantischen Zirkulation auf Grund der "Meteor." Ergebnisse Kieler Meeresforschungen, 7, fig. 1. Kiel: Institut für Meereskunde der Universität Kiel. 